\title{
Spatiotemporal variations of zooplankton community in a shallow tropical brackish lagoon (Sontecomapan, Veracruz, Mexico)
}

\author{
Marcela I Benítez-Díaz Mirón ${ }^{1 *}$, María E Castellanos-Páez², Gabriela Garza-Mouriño², María J Ferrara-Guerrero ${ }^{3}$ \\ and Marc Pagano ${ }^{4}$
}

\begin{abstract}
Background: We studied the relationships between zooplankton distribution and environmental and trophic factors (abiotic variables, nutrients, bacterial biomass, and chlorophyll pigments) from three sampling surveys carried out during the three hydrological seasons (rainy, dry, and norte) in a tropical coastal lagoon connected to the sea.

Results: Twenty eight (28) of the 54 taxa recorded were identified to species level, of which 3 genera of Cladocera were observed for the first time in the lagoon. Season-specific differences were highly significant. The overall zooplankton abundance was significantly higher during the dry season $\left(157,000 \mathrm{ind} . \mathrm{m}^{-3}\right)$ than those during the rainy and norte surveys (means of 11,600 and 16,700 ind. $\mathrm{m}^{-3}$ respectively). Copepoda (mostly nauplii) was the most abundant group (>83\%) of total zooplankton abundance.

Conclusions: Multivariate (coinertia) and multilinear regression analyses showed that transparency, salinity, temperature, $\mathrm{pH}$, and food availability (Chl $a, b$, and c) were the main determinants of zooplankton abundance, composition, and diversity, explaining the seasonal differences. The relatively low zooplankton density in the lagoon compared to other eutrophic lagoons is attributed to the combined effects of high water exchanges, low depth, and high transparency, which favor instability and vulnerability to UV effects and/or to visual predation.
\end{abstract}

Keywords: Sontecomapan; Zooplankton; Brackish lagoon; Shallow lagoon; Environmental factors

\section{Background}

Coastal lagoons are often considered as hot spots for biodiversity and are among the most productive ecosystems in the world due to higher nutrient inputs from their catchment basin. However, they are considered as one of the most affected environments by anthropogenic activities (Kemp and Boynton 2012). Increased anthropogenic activities may accelerate the eutrophication process leading to dystrophic crises and/or irreversible deterioration (Bartoli et al. 2001). These highly productive and vulnerable ecosystems are subjected to a strong variability at both spatial and temporal scale (Marinov et al. 2008) and need to be protected and managed rationally to continue to play their ecological and socio-economic role.

\footnotetext{
*Correspondence: mbenitez@correo.xoc.uam.mx

'Universidad Autónoma Metropolitana, Unidad Xochimilco, Doctorado en Ciencias Biológicas y de la Salud, Calzada del Hueso 1100, Col Villa Quietud, Delegación Coyoacán CP 04960DF, México

Full list of author information is available at the end of the article
}

Zooplankton is considered as a sensitive tool for monitoring environmental changes in these lagoons because its sensitivity to trophic (Marcus 2004; Pinto-Coelho et al. 2005) and salinity conditions (Kibirige and Perissinotto 2003; Santangelo et al. 2007) and its considerable fluctuations induced by abiotic and biotic factors (Naumenko 2009). Zooplankton also constitutes one of the main subsystems in water bodies, transferring energy from autotrophic organisms or microzooplankton to higher trophic levels and regulating sedimentation and cycling of nutrients (nitrogen, phosphorus, carbon) (Eyre 2000; Eyre and McKee 2002; Lassalle et al. 2013). It also includes larvae of nektonic and benthic animals having a part of their life cycle in the plankton, and this meroplankton may be economically very important in coastal and lagoon waters (David et al. 2006; Kirby et al. 2008). Thus, any change in the composition and functioning of the zooplankton community affects the state of the whole ecosystem. 
The patterns and processes of zooplankton spatial and temporal distribution are thus important prerequisite for ecosystem modeling and rational management of coastal lagoons. Traditionally, plankton seasonality is assumed to be less prominent in low-latitude than in high-latitude environments due to the dampened fluctuations in both irradiance and temperature in the tropical zone. However, many tropical or sub-tropical aquatic ecosystems are sensitive to seasonal variations in hydrology due to annual cycles of precipitation; this seasonality occurs both directly through flushing and indirectly through hydrological effects on nutrient cycling by particle resuspension and run-off (De Senerpont et al. 2013).

In Mexico, 111 coastal lagoons have been registered (Contreras 1993); however, detailed studies on the zooplankton dynamics are still scarce. Some works confined to only one taxonomic group; for example, the distribution of freshwater rotifers are well documented (Rico-Martinez and Silva-Briano 1993; Nandini et al. 2008), as where copepods in coastal (Álvarez-Silva and Gómez-Aguirre 2000; Pantaleón-López et al. 2005; Álvarez-Cadena et al. 2009), marine, and inland waters (Suárez-Morales and Reid 1998; Suárez-Morales 2004; Suárez-Morales et al. 2011). Those studies that include the dynamics of the brackish zooplankton (Escamilla et al. 2001; Pantaleón-López et al. 2005; De Silva-Davila et al. 2006) usually omit the smaller taxonomic groups like rotifers. Until now, only two published papers are available at species level for rotifers and cladocerans from Mexican brackish waters (Mecoacan lagoon (Sarma et al. 2000) and Sontecomapan lagoon (Castellanos-Páez et al. 2005)). More recently, two works have been published about the rotifers diversity of inland saline waters contributing to 22 new records from Mexico (Wallace et al. 2005, 2008).

In summary, the importance of abiotic and biotic forces and that of the biophysical coupling in structuring planktonic communities has been demonstrated in many aquatic systems all over the world (Pinel-Alloul and Ghadouani 2007). However, the patterns and processes of zooplankton spatial and temporal distribution are poorly known in Mexican coastal lagoons.

The purposes of the present work were (1) to test whether the variability of abiotic (transparency, $\mathrm{pH}$, salinity, temperature, etc.) and biotic (composition and abundance of microbial components) factors can significantly drive the seasonal and spatial patterns of zooplankton in shallow tropical coastal lagoons and (2) to contribute filling the knowledge gap about the zooplankton dynamics in mexican lagoons.

\section{Methods}

The Sontecomapan lagoon is a tropical coastal lagoon located on the coast of Veracruz State, in the Gulf of
Mexico $\left(18^{\circ} 30^{\prime}\right.$ to $18^{\circ} 34^{\prime} \mathrm{N}$ y $94^{\circ} 47^{\prime}$ to $95^{\circ} 11^{\prime} \mathrm{W}$ ) (Figure 1). The lagoon has an area of $12 \mathrm{~km}$ length and $1.5 \mathrm{~km}$ width with an average depth of $1.5 \mathrm{~m}$ and a maximum depth of $7 \mathrm{~m}$ at the mouth. It is permanently connected to the Gulf of Mexico. High spatiotemporal salinity fluctuation is recorded due to differential intrusion of freshwater and seawater. There are three hydrological seasons: rainy, dry and 'norte' (strong winds from the North). During the rainy season (June to October), the lagoon receives a continuous freshwater inflow from small rivers. In contrast, at the peak of the dry season (January to May), the lagoon shows marine salinities. During the norte season (November to December), the lagoon displays intermediate conditions and behaves like a brackish water body (Aké-Castillo and Vázquez 2008, 2011).

Three sampling surveys, covering a network of 10 stations having different characteristics (see Figure 1, Table 1) were realized in March (26 to 29), June (11 to 14 ), and November (19 to 22) 2010 corresponding to dry, rainy, and norte seasons, respectively. During each survey, the ten stations were sampled one time for environmental variables, bacterial abundance, chlorophyll concentration, and zooplankton. All sampling and measurements were performed during the day (between 9:00 a.m. and 04:00 p.m.).

\section{Sediment composition}

The percentage of sand, silt, and clay in the inorganic fraction of sediments was measured according to the standard Bouyoucos procedure. First, the samples were treated with sodium hexametaphosphate to complex $\mathrm{Ca}^{2+}, \mathrm{Al}^{3+}$, $\mathrm{Fe}^{3+}$, and other cations that bind clay and silt particles into aggregates. The density of the soil suspension was determined with a hydrometer calibrated to read in grams of solids per liter after the sand settles down and again after the silt settles (Bouyoucos 1962). The organic matter content was determined by standard method (Walkey and Black 1934).

\section{Water column abiotic variables}

The transparency was measured using a Secchi disk. Water samples were collected at two levels (near the bottom and in subsurface) with a Van Dorn bottle. Several measurements were made immediately after the collection: temperature and $\mathrm{pH}$ were measured with a portable pH meter Centronics model $49( \pm 0.01)$ (Centronics, Hudson, New Hampshire, USA), salinity with a portable refractometer (Speer 300011, Speer, Scottsdale, AZ, USA) and concentration of dissolved oxygen was determined using the Winkler method (Strickland and Parsons 1972). Subsamples were preserved at $-11^{\circ} \mathrm{C}$ for subsequent analyses of nutrients [phosphate $\left(\mathrm{PO}_{4}^{3-}\right)$, ammonium $\left(\mathrm{NH}_{4}\right)$, nitrite $\left(\mathrm{NO}_{2}\right)$, and nitrate $\left(\mathrm{NO}_{3-}\right)$ ], according to standard Hach protocols $8190,10023,10205$, and 8192, respectively. 


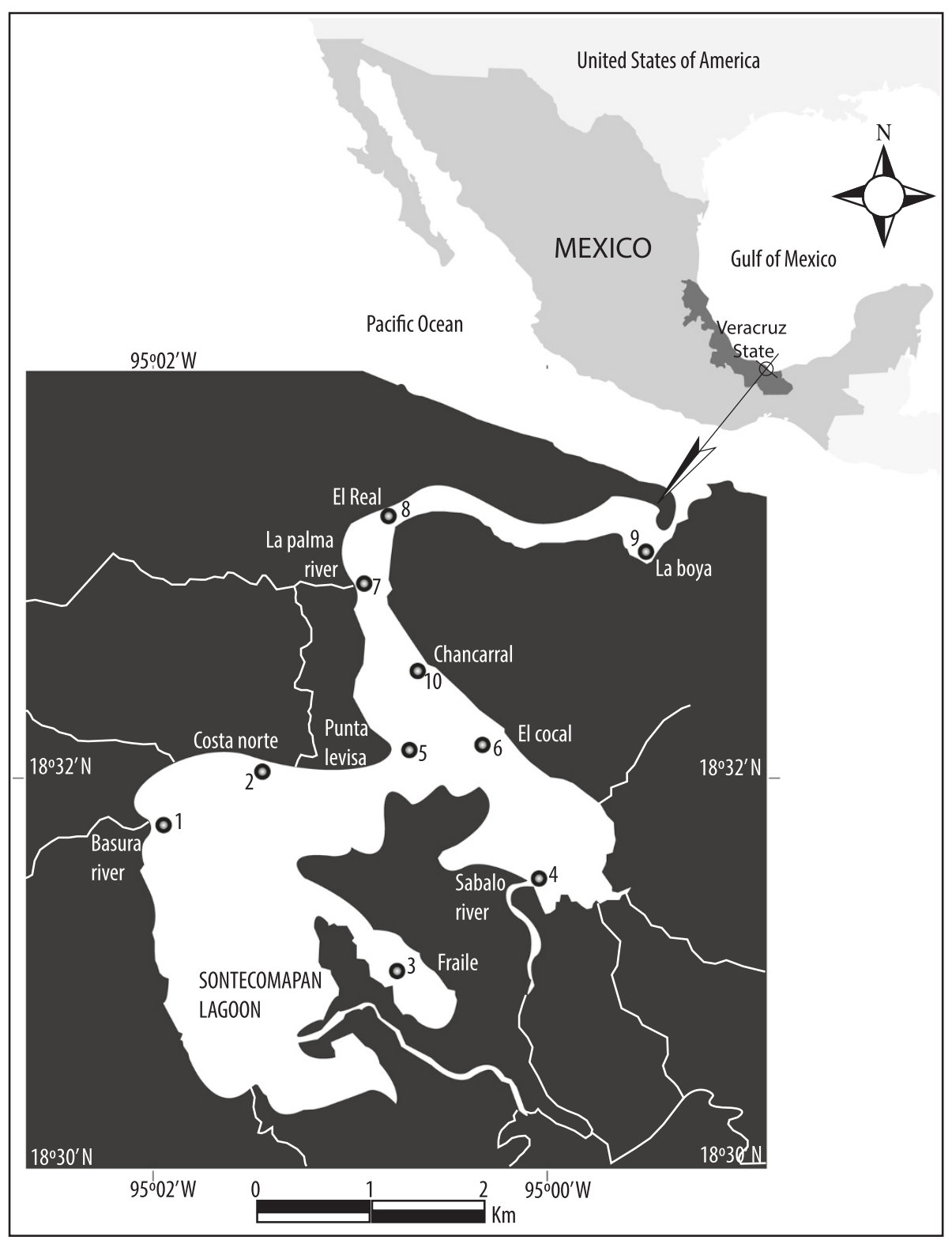

Figure 1 Sontecomapan coastal lagoon map, showing the ten sampling stations.

\section{Biotic variables}

In order to determine the bacterial abundance and biomass, samples of $10 \mathrm{ml}$ were preserved with formaldehyde borato-buffered ( $2 \%$ final concentration) and stored in dark at $4^{\circ} \mathrm{C}$. From each sample, $1 \mathrm{ml}$ were stained in the dark with 4,6-diamidino-2-phenylindole (DAPI; $1.8 \mathrm{mg} \mathrm{l}^{-1}$ final concentration) (Porter and Feig 1980) and filtered on $0.22 \mathrm{~mm}$ black polycarbonate filters. The filters that contain the samples were mounted on slides and stored frozen until analysis. The bacterial enumeration was done using the photomicrographies taken under UV excitation in an Olympus BX-50 epifluorescence microscope (Olympus Corporation, Shinjuku-ku, Japan) and a Lumenera camera
(Ottawa, ON, Canada). For each filter, 20 random fields of $250 \mu^{-2}$ were analyzed in the Image Pro Plus 7.1. All cells were counted and measured to calculate cell volumes $\left(\mu \mathrm{m}^{3}\right)$ and then were converted to cell carbon (pg C cell $\left.{ }^{-1}\right)$ using conversion carbon of $0.35 \mathrm{pg} \mathrm{C} \mathrm{m}^{3}$ for heterotrophic bacteria (Bjørnsen 1986). The carbon biomasses were estimated by multiplying the cell carbon by their abundances.

To analyze the photosynthetic chlorophyll pigment (Chl $a, b, c_{1}$, and $c_{2}$ ), 11 water (previously filtered through $64 \mu \mathrm{m}$ net) was passed through a glass fiber filter (GF/C Whatman, Maidstone, UK). At the end of the filtration, $0.2 \mathrm{ml}$ of $\mathrm{MgCO}_{3}$ suspension was added to the final few 
Table 1 Geographic location of sampling sites, median composition of the sediment, and coefficient of pollution

\begin{tabular}{llllllll}
\hline Number & Station & Type & Depth $\mathbf{( c m})$ & \% Organic matter & \% Silts and clays & \% Sands & Coefficient of pollution \\
\hline 1 & Río Basura & 1 & 77 & $8.3 \pm 8.8$ & $36 \pm 31.2$ & $46 \pm 0$ & 1.79 \\
2 & Costa Norte & 2 & 80 & $0.4 \pm 0.2$ & $7.3 \pm 1.2$ & $92.7 \pm 1.2$ & 1.94 \\
3 & El Fraile & 2 & 88 & $3.5 \pm 2.4$ & $55.3 \pm 5.8$ & $44.7 \pm 5.8$ & 3.36 \\
4 & El Sábalo & 1 & 240 & $\mathrm{ND}$ & $\mathrm{ND}$ & $\mathrm{ND}$ & $\mathrm{ND}$ \\
5 & Punta Levisa & 2 & 47 & $4.6 \pm 4.4$ & $16.7 \pm 1.2$ & $83.3 \pm 1.2$ & 3.26 \\
6 & El Cocal & 2 & 171 & $\mathrm{ND}$ & $\mathrm{ND}$ & $\mathrm{ND}$ & $\mathrm{ND}$ \\
7 & La Palma & 1 & 103 & $0.6 \pm 0.6$ & $12 \pm 0$ & $88 \pm 0$ & 1.07 \\
8 & El Real & 3 & 255 & $0.1 \pm 0.1$ & $9.3 \pm 8.1$ & $86 \pm 0$ & 2.46 \\
9 & La Boya & 3 & 124 & $1.8 \pm 0.4$ & $21.3 \pm 1.2$ & $78.7 \pm 1.2$ & 0.81 \\
10 & El Chancarral & 3 & 105 & $1.6 \pm 0.6$ & $24 \pm 0$ & $76 \pm 0$ & 2.16 \\
\hline
\end{tabular}

Type 1 stations have direct input of freshwater, type 2 without direct input of freshwater, and type 3 are those with a strong marine influence. The values correspond to the average \pm standard deviation.

milliliters to prevent the pigment deterioration and stored for a few hours in a dark and cool place $\left(4^{\circ} \mathrm{C}\right)$.

The chlorophyll pigments extraction was done following the method of Vernick and Hayward (1984), and the calculations for determination of chlorophyll was made according to the equations of Jeffrey and Humphrey (1975).

\section{Zooplankton}

The zooplankton was collected using a cylindro-conical net (64 $\mu \mathrm{m}$ in mesh opening size, $30 \mathrm{~cm}$ in mouth diameter, and $1 \mathrm{~m}$ in length). Samples were preserved with $4 \%$ formalin. Species identification was made according to Koste (1978) and Segers (1995) for rotifers and Rose (1933), Tregouboff and Rose (1957), Carli and Crisafi (1983), Suárez-Morales and Elías-Gutiérrez (2000), SuárezMorales (2004), and Razouls et al. (2005-2013) for copepods and other taxonomical groups. The taxa were identified and counted under an optical microscope Olympus BMX50 and dissecting microscope Nikon SMZ500 (Nikon, Chiyoda, Tokyo, Japan), respectively. Zooplankton densities, expressed as numbers per cubic meter, were calculated by dividing the number of organisms estimated in each sample by the volume of water filtered in the field (cylinder defined by the net opening area and the length of the drag). The taxonomic diversity was estimated using the Shannon index calculated without taking in account the copepod nauplii, which included miscellaneous species.

\section{Data processing}

Two-way analyses of variance (ANOVAs, with a general linear model) were performed to test the effects of sampling survey (dry season, rainy season, and norte), stations, and their interactions on the biotic and abiotic parameters and on zooplankton. Tukey's post hoc test of honest significant difference (HSD) was also performed to compare the mean group values.
Stepwise multiple regression analyses were conducted to explain the variability in zooplankton distribution. Relationships were tested between zooplankton parameters (total abundance, abundances of the main groups, and species), abiotic (transparency, temperature, salinity, oxygen), and biotic (bacterial abundance and biomass, chlorophyll $a, b$, and $c$ ) parameters.

The spatial and seasonal variability of environmental variables and zooplankton communities was assessed using multivariate analysis after data transformation $(\log +1)$. To avoid the effects of underrepresentative species, a procedure was used to select taxa from the faunistic list based on their contribution to the population diversity as expressed by the Shannon diversity index (Lam-Hoai et al. 2006). Only those taxa making a contribution to the index higher than $0.6 \%$ were considered (e.g., 28 taxa over the 54 identified). For environmental variables, mean bottom subsurface values were considered, and additionally, we considered the difference between bottom and surface values for salinity and oxygen as proxy for stratification status.

The analysis was realized using two data sets: the first one featured the abundances of zooplankton taxa and the second one the environmental and trophic variables. Factorial correspondence analysis (FCA) and principal component analysis (PCA) were performed on these two data sets, respectively. The results of the two analyses were associated through a coinertia analysis (Doledec and Chessel 1994). Analyses were performed using ADE4 software (Thioulouse et al. 1997).

\section{Results}

\section{Sediment composition}

The Sontecomapan lagoon shows a high variability of sediment composition (Table 1). There was an important variation of the percentage of organic matter 
content $(\mathrm{OM})$. Station 8 presented the lowest $\mathrm{OM}$ percentage $(0.1 \%)$ and could be classified as extremely poor according to Walkey and Black (1934) classification. It was followed by stations $2(0.4 \%)$ and $7(0.6 \%)$ typified as very poor and poor, respectively, whereas stations 9 $(1.8 \%)$ and $10(1.6 \%)$ reached medium contents. Station 3 (3.5\%) was considered as very rich, and stations 1 (8.3\%) and $5(4.6 \%)$ as extremely rich in organic matter.

The mineral fraction was dominated by sands in stations $2,5,7,8,9$, and $10(>75 \%)$, while fine fractions (silts and clays) were relatively important in stations $1(36 \%)$ and 3 (55\%).

\section{Water column abiotic variables}

Statistical descriptors and seasonal (survey) variations for environmental parameters are shown in Table 2. Mean bottom surface values were considered.

Water transparency varied between 25 to $380 \mathrm{~cm}$ representing $19 \%$ to $100 \%$ of the total water column depth, but, despite high variability, showed no significant difference between stations or surveys (ANOVA, $p>0.05$ ).

Temperature varied between $23.2^{\circ} \mathrm{C}$ and $28.6^{\circ} \mathrm{C}$ and displayed significantly higher values during the rainy season than during the two other surveys (ANOVA, $p<0.05$ ) but showed no significant difference between stations $(p=0.78)$.

Table 2 Variations in environmental parameters

\begin{tabular}{|c|c|c|c|}
\hline $\begin{array}{l}\text { Variables } \\
\text { (symbols, unit) }\end{array}$ & $\begin{array}{l}\text { Dry } \\
(\text { mean } \pm S D)\end{array}$ & $\begin{array}{l}\text { Rainy } \\
\text { (mean } \pm \text { SD) }\end{array}$ & $\begin{array}{l}\text { Norte } \\
(\text { mean } \pm \text { SD) }\end{array}$ \\
\hline \multirow[t]{2}{*}{ Depth $(\mathrm{cm})$} & $110.7 \pm 70.2$ & $157.5 \pm 100.2$ & $118.6 \pm 91.8$ \\
\hline & (35 to 280 ) & (24.6 to 380$)$ & (30 to 320 ) \\
\hline \multirow[t]{2}{*}{ Transparency (cm) } & $69.8 \pm 29.2$ & $82.5 \pm 106.7$ & $44.8 \pm 25.5$ \\
\hline & (31 to 115 ) & (24.6 to 380$)$ & (25 to 100$)$ \\
\hline \multirow[t]{2}{*}{ Temperature $\left({ }^{\circ} \mathrm{C}\right)$} & $24.8 \pm 1.0$ & $26.4 \pm 1.2$ & $24.7 \pm 1.3$ \\
\hline & (23.4 to 27 ) & (24.6 to 28.6$)$ & (23.2 to 27.3 ) \\
\hline \multirow[t]{2}{*}{ Salinity } & $17.9 \pm 9.9$ & $10.4 \pm 3.7$ & $11 \pm 8.6$ \\
\hline & (4 to 32 ) & (2.4 to 14$)$ & (2 to 27 ) \\
\hline \multirow[t]{2}{*}{$\mathrm{pH}$} & $7.3 \pm 0.4$ & $7.2 \pm 0.3$ & $8.1 \pm 0.6$ \\
\hline & (6.61 to 7.7 ) & (6.7 to 7.74 ) & (7.05 to 8.98$)$ \\
\hline \multirow[t]{2}{*}{ Dissolved oxygen $\left(\mathrm{O}_{2} \mathrm{~m} \mathrm{I}^{-1}\right)$} & $5.6 \pm 0.5$ & $4.8 \pm 1.3$ & $4.8 \pm 1.2$ \\
\hline & (4.9 to 6.5$)$ & (2.52 to 6.5$)$ & (2.6 to 6.45$)$ \\
\hline \multirow[t]{2}{*}{ Nitrites $\left(\mathrm{NO}_{2} \mathrm{mg} \mathrm{l}^{-1}\right)$} & $0.00 \pm 0.0$ & $0.005 \pm 0.006$ & $0.014 \pm 0.008$ \\
\hline & (0.00 to 0.045$)$ & (0.00 to 0.02$)$ & (0.004 to 0.03$)$ \\
\hline \multirow[t]{2}{*}{ Nitrates $\left(\mathrm{NO}_{3} \mathrm{mg} \mathrm{l}^{-1}\right)$} & $0.100 \pm 0.1$ & $1.210 \pm 1.021$ & $0.028 \pm 0.031$ \\
\hline & (0.00 to 0.4$)$ & (0.0 to 3.0$)$ & (0.01 to 0.11$)$ \\
\hline \multirow[t]{2}{*}{ Ammonium $\left(\mathrm{NH}_{4}\left(\mathrm{mg} \mathrm{l}^{-1}\right)\right)$} & $0.6 \pm 0.4$ & $0.093 \pm 0.057$ & $0.036 \pm 0.023$ \\
\hline & (0.12 to 1.2$)$ & (0.0 to 0.22$)$ & (0.02 to 0.09$)$ \\
\hline \multirow[t]{2}{*}{ Phosphates $\left(\mathrm{PO}_{4}^{-} \mathrm{mg} \mathrm{l}^{-1}\right)$} & $0.2 \pm 0.1$ & $1.731 \pm 2.5$ & $1.867 \pm 2.811$ \\
\hline & (0.12 to 0.3$)$ & (0.22 to 7.2$)$ & (0.08 to 6.84$)$ \\
\hline \multirow[t]{2}{*}{ Bacterial density $\left(\mathrm{BD}\left(\right.\right.$ cells.ml $\left.\left.{ }^{-1} \times 10^{6}\right)\right)$} & $2.9 \pm 2.1$ & $3.8 \pm 1.8$ & $4.5 \pm 1.3$ \\
\hline & (0.67 to 8.3$)$ & (1.3 to 6.9$)$ & (2.6 to 6.72 ) \\
\hline \multirow[t]{2}{*}{ Bacterial biomass (BBM $\left.\left(\mu \mathrm{g} \cdot \mathrm{C} \cdot \mathrm{m}^{-3}\right)\right)$} & $2.6 \pm 0.9$ & $2.7 \pm 1.4$ & $4.3 \pm 2.1$ \\
\hline & (1.2 to 3.8$)$ & $(0.7$ to 4.5$)$ & (1.8 to 9.3$)$ \\
\hline \multirow[t]{2}{*}{ Chlorophyll $a\left(\mathrm{CHLA}\left(\mathrm{mg} \mathrm{I}^{-1}\right)\right)$} & $1.2 \pm 0.5$ & $3.8 \pm 3.9$ & $0.7 \pm 0.5$ \\
\hline & (0.5 to 1.9$)$ & (0.05 to 18.3$)$ & (0.06 to 1.6$)$ \\
\hline \multirow[t]{2}{*}{ Chlorophyll b (CHLB $\left.\left(\mathrm{mg} \mathrm{I}^{-1}\right)\right)$} & $0.5 \pm 0.7$ & $1.4 \pm 1.3$ & $0.8 \pm 0.6$ \\
\hline & (0.1 to 2.4$)$ & (0.24 to 4.1$)$ & (0.07 to 1.9$)$ \\
\hline \multirow[t]{2}{*}{ Chlorophyll c (CHLC $\left.\left(\mathrm{mg} \mathrm{l}^{-1}\right)\right)$} & $4.0 \pm 3.4$ & $1.4 \pm 1.3$ & $0.3 \pm 0.3$ \\
\hline & (0.2 to 9.6$)$ & (0.21 to 4.4$)$ & $(0.004$ to 0.9$)$ \\
\hline
\end{tabular}

Numbers in body are mean \pm standard deviation (SD), and ranges are enclosed in parentheses. 
Salinity varied between 2 and 32 according to the stations and the surveys (Figure 2A). It displayed significantly higher mean value during the dry season (17.9) than during the rainy (10.4) and the norte (11) surveys (ANOVA, $p<0.05)$. There was a high variability between stations, with lowest values always recorded at station 1 (Figure 2A). Difference between surface and bottom salinity varied between 0 and 32 (Figure 2B) and displayed no significant variation between stations or surveys (ANOVA, $p>0.05$ ). However, very high values $(>15)$ occurred at stations 2 and 7 during the dry season and at stations 3, 6, and 9 during the norte survey.

The $\mathrm{pH}$ varied between 6.61 and 8.98 and was significantly higher during the norte survey than during the two other ones (ANOVA, $p<0.05$ ). Besides, mean $\mathrm{pH}$ values at stations 1 and 7 were significantly lower than at the other stations (Figure 2C).

Dissolved oxygen varied between 2.52 and $6.5 \mathrm{mg} \mathrm{l}^{-1}$ (Table 2) with difference between surface and bottom

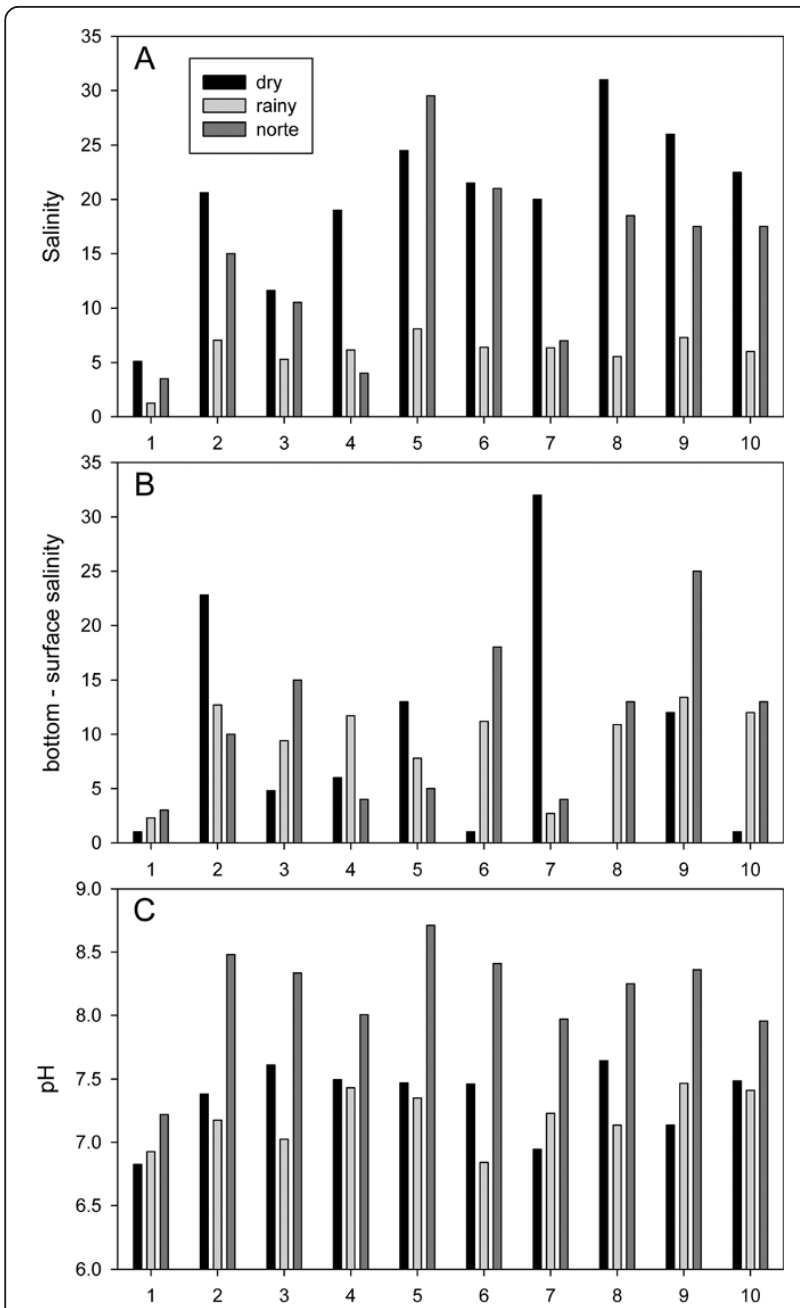

Figure 2 Spatial variability of (A) water column salinity, (B) salinity bottom surface difference, and (C) $\mathrm{pH}$. values ranging between 0.1 and $3.8 \mathrm{mg} \mathrm{l}^{-1}$. None of these variables displayed significant variation between stations or surveys (ANOVA, $p>0.05$ ).

Nitrites displayed very low values ranging from 0 to $0.03 \mathrm{mg} \mathrm{l}^{-1}$ and showed no significant difference between surveys (ANOVA, $p>0.05$ ) (Table 2). Nitrates showed significant higher values during the rainy season (mean = $1.21 \mathrm{mg} \mathrm{l}^{-1}$, with values up to $3 \mathrm{mg} \mathrm{l}^{-1}$ ) than during the two other surveys $\left(<0.3 \mathrm{mg} \mathrm{l}^{-1}\right)$ (Figure $\left.3 \mathrm{~A}\right)$. In contrast, ammonium concentration was significantly higher during the dry season (mean $=0.6 \mathrm{mg} \mathrm{l}^{-1}$, with values up to $\left.1.2 \mathrm{mg} \mathrm{l}^{-1}\right)$ than during the two other surveys $\left(<0.1 \mathrm{mg} \mathrm{l}^{-1}\right)$ (Figure $3 \mathrm{~B})$. None of these nitrogen nutrients displayed significant difference between stations.

Phosphate concentration was significantly lower during the dry season $\left(<0.2 \mathrm{mg} \mathrm{l}^{-1}\right)$ than during the two other surveys (mean $=1.73$ and $1.87 \mathrm{mg} \mathrm{l}^{-1}$ in the rainy and norte seasons, respectively), but these differences were mainly linked to stations $1,3,4,8$, and 9 while very

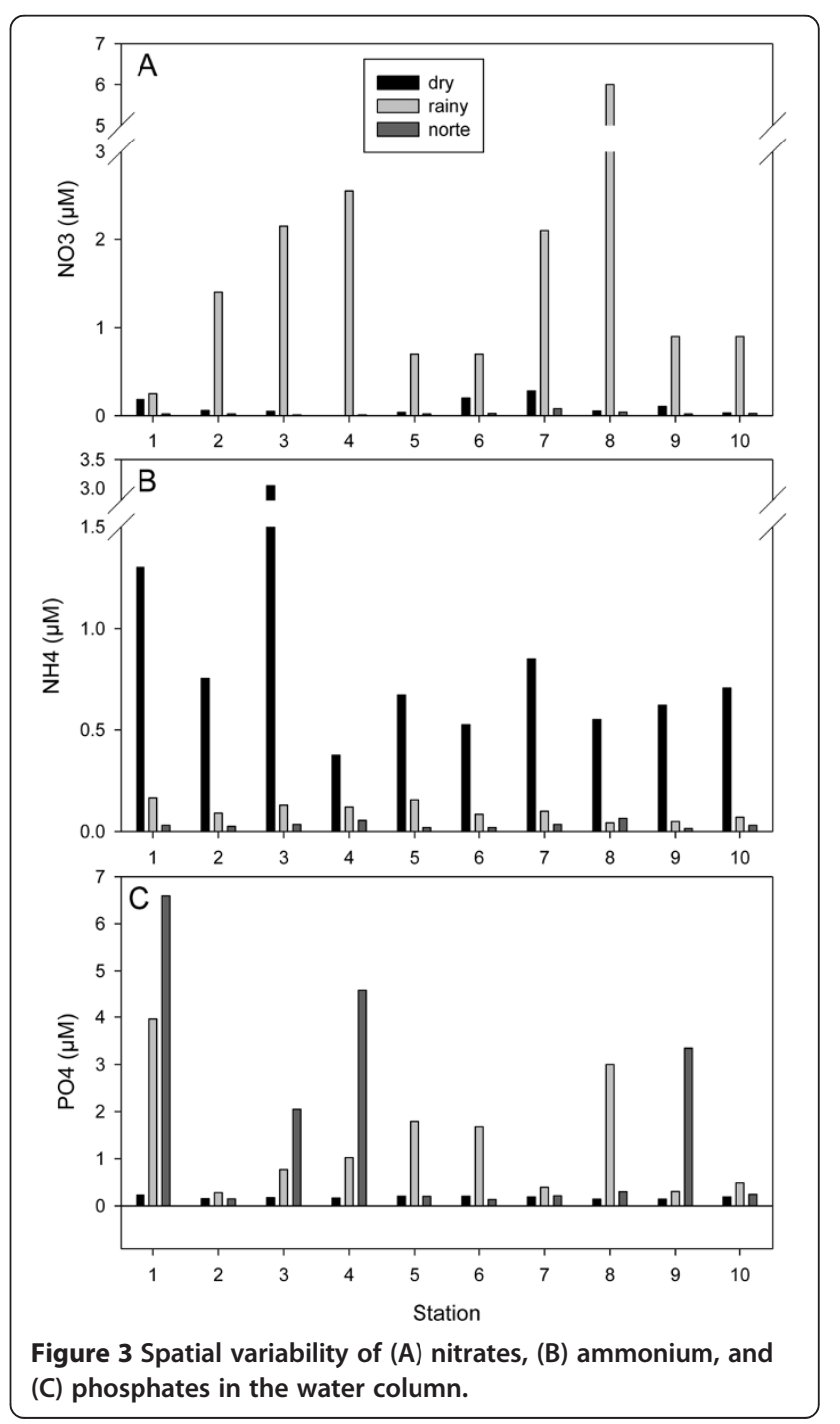


low values were observed at stations 2,7 , and 10 during the three surveys (Figure 3C).

\section{Biotic variables}

Bacterial density and biomass ranged from 0.67 to $8.3 \times$ $10^{6}$ cell ml $^{-1}$ and from 0.7 to $9.3 \mu$ g.C.m ${ }^{-3}$, respectively. They were significantly higher during the norte survey than during the two other ones (ANOVA, $p<0.05$ ), while there was no significant difference between stations.

Except at station 1, chlorophyll $a$ content was the highest (up to $18.3 \mu \mathrm{g} \mathrm{l}^{-1}$ ) during the rainy survey and lowest (up to $1.6 \mu \mathrm{g} \mathrm{l}^{-1}$ ) during the norte (Table 2, Figure 4A). Chlorophyll $b$ showed no significant difference between stations or surveys (ANOVA, $p>0.05$ ). However, stations 1 to 4 displayed lower chlorophyll $b$ values during the rainy survey than during the two other ones, while a reverse trend was observed at stations 5 to 9 (Figure 4B). Chlorophyll $c$ displayed significantly higher values during

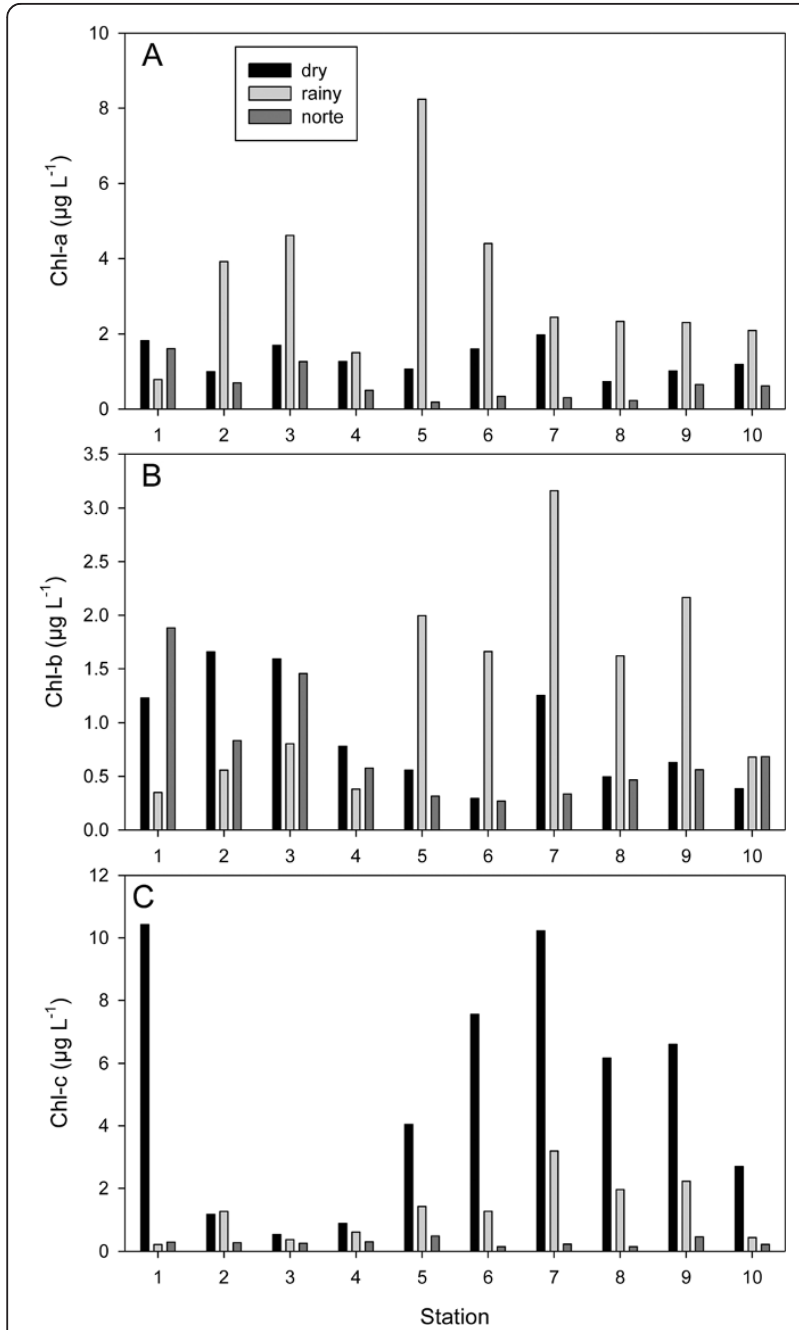

Figure 4 Spatial variability of (A) chlorophyll $a$, (B) chlorophyll $b$, and $(C)$ chlorophyll $c_{1}$ and $c_{2}$. the dry season survey (mean $=4.0 \mu \mathrm{g} \mathrm{l}^{-1}$, with values up to $9.6 \mu \mathrm{g} \mathrm{l}^{-1}$ ) surveys than during the rainy and the norte surveys (mean $=1.4$ and $0.3 \mu \mathrm{g} \mathrm{l} \mathrm{l}^{-1}$, respectively). Stationspecific differences in chlorophyll $c$ content was not significant (ANOVA, $p>0.05$ ); however, chlorophyll $c$ value

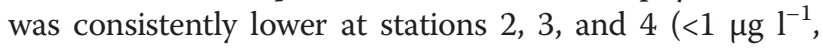
Figure 4C).

\section{Zooplankton}

Fifty-five zooplankton taxa were enumerated in the 10 stations during the 3 surveys (Table 3 ). They included 21 rotifers, 17 copepods (including miscellaneous nauplii) 3 cladocerans, 7 miscellaneous other holoplanktonic groups (ostracods, polychaetes, nematods, appendicularians, chaetognaths hydrachnida, and water mites), and 6 meroplankton taxa (polychaete, fish, chironomid, gastropod, bivalve, cirriped, and decapod larvae).

The number of taxa per sample varied between 2 (station 4, norte survey) and 24 (station 2, dry season survey) (Figure 5A) and was significantly higher during the dry and rainy surveys than during the norte survey, while no significant difference was recorded between stations.

Shannon diversity index varied between 0 and 3.8 bit ind $^{-1}$ and was significantly higher during the dry and rainy surveys than during the norte survey (Figure 5B). It was also significantly lower at stations 3 and 4 than in all other stations.

Total zooplankton abundance varied between 280 and 1,300,000 ind. $\mathrm{m}^{-3}$ (Figure 5C) and showed no significant difference between stations or surveys (ANOVA, $p>0.05$ ). However, stations 7,8 , and 9 always displayed very low abundances $\left(<3,600\right.$ ind. $\left.\mathrm{m}^{-3}\right)$ while stations 4,6 , and 10 during the dry season survey and station 3 during the norte survey displayed the highest abundances $\left(>60,000\right.$ ind. $\left.\mathrm{m}^{-3}\right)$.

Copepods were the most important group representing $31.1 \%$ to $99.7 \%$ of the total zooplankton abundance and nauplii ( $25.3 \%$ to $99.5 \%$ ) mainly contributed to this dominance (Table 3).

The top two highly abundant copepod species were Acartia tonsa and Oithona nana, which were present in more than $80 \%$ of the samples and represented up to $100 \%$ and $77 \%$ of the non-naupliar copepod abundance, respectively. Paracalanus aculeatus (43\% occurrence and up to $37 \%$ abundance), Euterpina acutifrons (20\% and up to 3\%), and Pseudodiaptomus sp. (17\% and up to $29 \%)$ were also rather well represented while the other species were scarce $(<10 \%$ occurrence).

Other holoplanktonic organisms were less important, rotifers, cladocerans, and miscellanous other groups representing less than $19 \%, 2 \%$, and $37 \%$ of the total zooplankton abundance, respectively.

Among rotifers, only one species, Brachionus plicatilis, was present in more than $50 \%$ of the samples. Lecane bulla 
Table 3 Seasonal abundances and abundance percentage of the zooplanktonic taxa identified

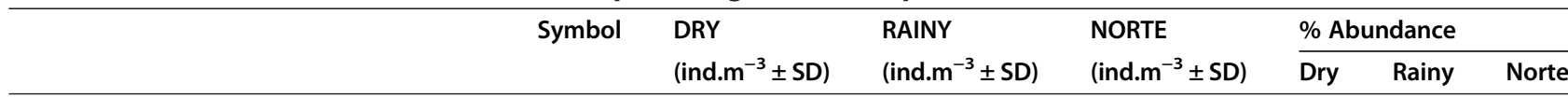

Phylum Rotifera Cuvier, 1817

Subclass Monogononta Plate, 1889

Superorder Pseudotrocha Kutikova, 1970

Order Ploima Hudson and Gosse, 1886

Family Brachionidae Ehrenberg, 1838

Brachionus plicatilis Müller, 1786

Brachionus angularis Gosse, 1851

Brachionus dimidiatus Bryce, 1931

Keratella americana Carlin, 1943

Keratella quadrata (Müller, 1786) ${ }^{\mathrm{a}}$

Platyias quadricornis (Ehrenberg, 1832)

Plationus patulus (Müller, 1786)

Family Euchlanidae Ehrenberg, 1838

Euchlanis incisa Carlin, 1939ª

Euchlanis dilatata Ehrenberg, $1832^{\mathrm{a}}$

Family Lecanidae Remane, 1933

Lecane bulla (Gosse, 1851)

Lecane quadridentata (Ehrenberg, 1830)

Lecane lunaris (Ehrenberg, 1832)

Lecane nana (Murray, 1913)

Family Lepadellidae Harring, 1913

Lepadella (Lepadella) donneri Koste, 1972

Lepadella (Lepadella) patella (Müller, 1773)

$R B p$
$R b d$
$R$
$R$
$R$
$R$
$R$
$R$
$R$
$R$
$R$
$R$
$R$
$R$
$R L$
$R L D$
$R$
$R$
$R$

$R B p$

$80.5 \pm 222.2$

$0.5 \pm 0.7$

2.05

0.17

0.07

Rba

$0.1 \pm 0.3$

$0.0 \pm 0.1$

$0.0 \pm 0.0$

$0.00 \quad 0.00$

0.00

$R B d$

$0.8 \pm 2.4$

$0.0 \pm 0.0$

$0.0 \pm 0.1$

$\begin{array}{ll}0.02 & 0.00\end{array}$

0.00

RKa

$0.0 \pm 0.1$

$0.0 \pm 0.0$

$0.0 \pm 0.0$

$0.00 \quad 0.00$

0.00

RKq

$0.1 \pm 0.2$

$0.0 \pm 0.0$

$0.0 \pm 0.0$

0.00

0.00

0.00

$R P q$

$1.1 \pm 3.3$

$0.1 \pm 0.1$

$0.0 \pm 0.0$

0.03

0.03

0.00

$R P p$

$0.0 \pm 0.1$

$0.0 \pm 0.0$

$0.0 \pm 0.0$

$0.00 \quad 0.00$

0.00

REi

$0.0 \pm 0.0$

$0.1 \pm 0.3$

$0.0 \pm 0.1$

$0.00 \quad 0.03$

0.00

REd

$0.1 \pm 0.2$

$0.0 \pm 0.0$

$0.0 \pm 0.0$

$0.00 \quad 0.00$

0.00

$R L b$

$1.5 \pm 4.0$

$0.0 \pm 0.0$

$0.6 \pm 1.7$

$0.04 \quad 0.00$

0.14

RLQ

$0.5 \pm 1.3$

$0.0 \pm 0.0$

$0.0 \pm 0.0$

0.01

0.00

0.00

RLI

$0.0 \pm 0.0$

$0.0 \pm 0.1$

$0.0 \pm 0.0$

$0.00 \quad 0.00$

0.00

RLn

$0.0 \pm 0.0$

$0.0 \pm 0.0$

$0.00 \quad 0.00$

0.00

RLd

$0.0 \pm 0.0$

$0.0 \pm 0.1$

$0.0 \pm 0.0$

0.00

0.00

0.00

RLP

$0.0 \pm 0.0$

$0.0 \pm 0.0$

$0.0 \pm 0.0$

$0.00 \quad 0.00$

0.00

Family Mytilinidae Harring, 1913

Mytilina ventralis (Ehrenberg, 1830)

$R M v$

$0.0 \pm 0.0$

$0.0 \pm 0.1$

$0.0 \pm 0.0$

$0.00 \quad 0.00$

0.00

Mytilina bisulcata (Lucks, 1912)

$R M b$

$0.5 \pm 1.6$

$0.0 \pm 0.0$

$0.0 \pm 0.0$

$0.01 \quad 0.00$

0.00

Family Synchaetidae Hudson and Gosse, 1886

Synchaeta oblonga Ehrenberg, 1832

RSO

$0.0 \pm 0.0$

$0.2 \pm 0.4$

$0.0 \pm 0.0$

$0.00 \quad 0.07$

0.00

Synchaeta bicornis Smith, 1904a

$0.0 \pm 0.0$

$0.3 \pm 0.5$

$0.0 \pm 0.0$

$0.00 \quad 0.10$

0.00

Family Trichotriidae Harring, 1913

Trichotria tetractis (Ehrenberg, 1830)

RTt

$0.1 \pm 0.4$

$0.0 \pm 0.0$

$0.0 \pm 0.0$

$0.00 \quad 0.00$

0.00

Superorder Pseudotrocha Kutikova, 1970

Order Flosculariaceae Harring, 1913

Family Testudinellidae Harring, 1913

Testudinella patina (Hermann, 1783)

RTp

$0.3 \pm 0.7$

$0.0 \pm 0.1$

$0.0 \pm 0.1$

0.00

0.00

0.00

Subphylum Crustacea

Class Branchiopodae

Order Cladocera

$$
\begin{aligned}
& \text { Chydorus sp. }{ }^{\text {a }} \\
& \text { Ceriodaphnia sp. }{ }^{\text {a }} \\
& \text { Penilia avirostris (Dana, 1849) }
\end{aligned}
$$$$
\text { CCh }
$$$$
0.1 \pm 0.2
$$

$0.0 \pm 0.0$

$0.0 \pm 0.0$

$0.00 \quad 0.00$

0.00

cCd

$0.1 \pm 0.2$

$0.0 \pm 0.0$

$0.0 \pm 0.0$

$0.00 \quad 0.00$

0.00

$\begin{array}{ll}C P & 0.0 \pm 0.0\end{array}$

$0.0 \pm 0.0$

$0.0 \pm 0.0$

$0.00 \quad 0.00$

0.00 
Table 3 Seasonal abundances and abundance percentage of the zooplanktonic taxa identified (Continued)

Class Maxillopoda

Subclass: Copepoda

Non identified nauplii

Cna

$2952 \pm 7647$

$249 \pm 294$

$393 \pm 552$

$75.2 \quad 85.6$

94.4

Superorder Gymnoplea

Order Calanoida

Family Acartiidae

Acartia tonsa Dana, 1852

CAt

$54.5 \pm 120.6$

$7.7 \pm 19.8$

$0.5 \pm 0.7$

$1.39 \quad 2.65$

0.12

Family Centropagidae

Centropages velificatus (Oliveira, 1947)

CCV

$0.0 \pm 0.0$

$0.4 \pm 1.1$

$0.0 \pm 0.0$

$0.00 \quad 0.14$

0.00

Family Paracalanidae

Paracalanus aculeatus Giesbrecht, 1888

$\mathrm{CPa}$

$5.4 \pm 10.3$

$0.9 \pm 1.0$

$0.2 \pm 0.6$

$0.14 \quad 0.31$

0.05

Family Clausocalanoidea

Phaenna sp. ${ }^{a}$

CHP

$0.0 \pm 0.0$

$0.0 \pm 0.0$

$0.0 \pm 0.0$

0

0.1

Family Temoridae

Temora turbinata (Dana, 1852)

CTt

$0.1 \pm 0.3$

$0.1 \pm 0.1$

$0.0 \pm 0.0$

$0.00 \quad 0.00$

0.00

Family Paeudodiaptomidae

Pseudodiaptomus sp.

CPd

$0.1 \pm 0.2$

$0.3 \pm 0.5$

$0.0 \pm 0.1$

0

0

Superorder Podoplea

Order Cyclopoida

Family Cyclopidae

Mesocyclops sp.

CMc

$0.0 \pm 0.0$

$0.0 \pm 0.1$

$0.0 \pm 0.0$

$0.00 \quad 0.03$

0.00

Family Oithonidae

Oithona nana (Giesbrecht, 1892) ${ }^{a}$

COn

$685.7 \pm$

$20.3 \pm$

$2.3 \pm$

Oithona sp

cosp

$0.0 \pm 0.0$

$0.9 \pm 2.8$

$0.0 \pm 0.0$

$0.2 \pm 0.4$

$0.0 \pm 0.0$

$0.5 \pm 1.6$

$0.0 \pm 0.0$

$0.1 \pm 0.2$

$0.0 \pm 0.0$

$0.1 \quad 0.5$

0

Family Tisbidae

Tisbe sp. ${ }^{a}$

CHT

$0.0 \pm 0.0$

$0.1 \pm 0.2$

$0.0 \pm 0.0$

$\begin{array}{lll}0.1 & 0.1 & 0\end{array}$

Other Harpacticoida

$$
\text { Canuella sp. a }
$$

$\mathrm{CHC}$

$0.0 \pm 0.1$

$0.0 \pm 0.0$

$0.7 \pm 2.0$

$1.6 \pm 1.7$

$0.2 \pm 0.3$

Unidentified 2

$\mathrm{CH} 1$

$4.0 \pm 5.1$

$0.0 \pm 0.1$

$0.0 \pm 0.0$

$0.3 \pm 0.4$

$0.0 \pm 0.0$

$0.5 \pm 1.0$

$0.0 \pm 0.0$

Appendicularia

Polychaeta (larvae)

Polychaeta (adults)

Osp

$4.5 \pm 12.2$

$1.0 \pm 1.2$

$1.0 \pm 1.2$

Plv

$15.1 \pm 33.0$

$0.1 \pm 0.1$

$0.0 \pm 0.1$

$0.7 \pm 1.3$

$0.0 \pm 0.0$

Chironomid larvae

Nsp

$0.4 \pm 0.5$

$0.0 \pm 0.0$

$0.0 \pm 0.0$

Hydrarachnidae

Chlv

$0.0 \pm 0.1$

$0.02 \pm 0.05$

$0.0 \pm 0.0$

$0.0 \pm 0.0$

$\begin{array}{lll}0 & 0.1 & 0 \\ 0 & 0.2 & 0\end{array}$

$\begin{array}{lll}0.3 & 0 & 0\end{array}$

$\begin{array}{lll}0 & 0 & 0.2\end{array}$


Table 3 Seasonal abundances and abundance percentage of the zooplanktonic taxa identified (Continued)

\begin{tabular}{|c|c|c|c|c|c|c|c|}
\hline Watermite & Wtm & 0.1 & $0.1 \pm 0.2$ & $0.0 \pm 0.0$ & 2 & 4 & 2 \\
\hline Chaetognatha & Chsp & $0.0 \pm 0.1$ & $0.1 \pm 0.2$ & $0.0 \pm 0.0$ & 1 & 1 & 0 \\
\hline Gasteropod larvae & Glv & $29.5 \pm 38.1$ & $0.8 \pm 1.0$ & $16.2 \pm 25.4$ & 7 & 8 & 8 \\
\hline Cyrripeda larvae & Cyl & $73.8 \pm 223.8$ & $3.8 \pm 4.9$ & $0.9 \pm 1.5$ & 8 & 9 & 6 \\
\hline Bivalve larvae & Blv & $1.8 \pm 5.6$ & $0.0 \pm 0.1$ & $0.4 \pm 1.3$ & 4 & 2 & 1 \\
\hline Decapod larvae & Dlv & $0.4 \pm 1.1$ & $0.0 \pm 0.1$ & $0.0 \pm 0.1$ & 3 & 2 & 1 \\
\hline Fish larvae & Flv & $0.2 \pm 0.4$ & $0.1 \pm 0.2$ & $0.0 \pm 0.0$ & 2 & 3 & 2 \\
\hline
\end{tabular}

Seasonal (survey) values of mean abundances ( \pm standard deviation, SD) and of abundance percentage of the zooplanktonic taxa identified. The symbols used for the multivariate analysis are shown in the second column. ${ }^{\text {a }}$ Species or genera recorded for first time in the lagoon.

(23\%), Synchaeta oblonga (17\%), Testudinella patina (17\%), Platyas quadricornis (13\%), and Synchaeta bicornis (13\%).

Cladocerans were represented by one marine species (Penilia avirostris) and two freshwater (Chydorus sp. and Ceriodaphnia sp.) species.

The other holplankton with an occurrence frequency $>10 \%$ were nematods (37\% occurrence), ostracods (30\%),

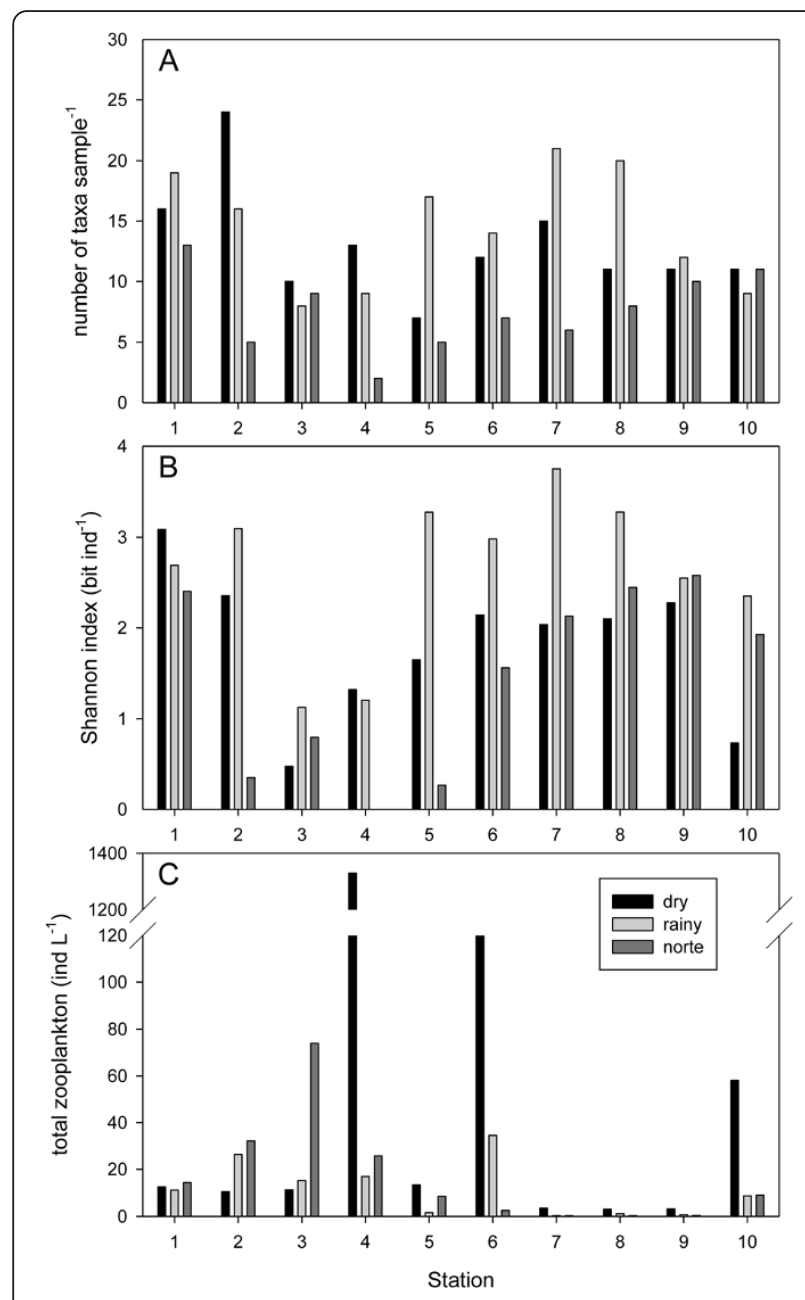

Figure 5 Spatial variability of (A) number of zooplankton taxa (B) Shannon diversity index and (C) total zooplankton abundance. hydrachnids (27\%), water mites (23\%), and appendicularians (17\%).

Meroplankton was present in all samples, except at station 10 during the rainy survey, and represented up to $19 \%$ of the total zooplankton abundance. It was mainly represented by cirriped, gastropod, and polychaete larvae (>70\% occurrence). Decapod (23\% occurrence), chironomids (20\%), bivalve (13\%), and fish (7\%) larvae were less represented.

The relative percentages of copepods, rotifers, and meroplankton showed no significant difference between stations or surveys (ANOVA, $p>0.05$ ). The percentage of other holoplanktonic groups was significantly higher during the rainy survey than during the two other ones $(p=0.046)$, but this was mainly due to the relative importance of appendicularia and nematoda (14\% to $37 \%)$ at stations 7,8 , and 9 where they compensated relatively low percentages of copepods (36\% to $78 \%$ ).

\section{Multiple regression analysis}

When considering the whole data set for the three surveys $(n=30)$, the water transparency had positive effects on diversity (Shannon index), but had negative relationships with total zooplankton, copepods, copepod nauplii, and $A$. tonsa (Table 4). Temperature had positive effects on marine rotifers (B. plicatilis and S. bicornis). Salinity had positive effects on total zooplankton, $A$. tonsa, and marine rotifers. $\mathrm{pH}$ had negative relationships with the number of taxa per sample, A. tonsa, and freshwater rotifers. Contrasted effects were shown for the three different chlorophyll forms ( $a, b$, and $c$ ). Chlorophyll $a$ had positive effects on copepod, copepod nauplii, and $A$. tonsa. Chlorophyll $b$ had positive effects on taxonomic richness (number of taxa) and on freshwater rotifers but negative effects on abundances of total zooplankton, copepods, nauplii, and A. tonsa. Chlorophyll $c$ had negative relationship with freshwater rotifers. When considering the three surveys separately $(n=10)$, most of the preceding relationships were not significant (Table 4). 
Table 4 Equation parameters of the multiple linear regression models

\begin{tabular}{|c|c|c|c|c|c|c|c|c|}
\hline & $\begin{array}{l}\text { Grouped data } \\
(n=30)\end{array}$ & & $\begin{array}{l}\text { Dry season survey } \\
(n=10)\end{array}$ & & $\begin{array}{l}\text { Rainy season surve } \\
(n=10)\end{array}$ & & $\begin{array}{l}\text { Norte season surve } \\
(n=10)\end{array}$ & \\
\hline & Beta & $p$ & Beta & $p$ & Beta & $p$ & Beta & $p$ \\
\hline Number of taxa & $R^{2}=0.62 ; p=0.0002$ & & $R^{2}=0.21, p=0.180$ & & $R^{2}=0.12 ; p=0.267$ & & $R^{2}=0.19 ; p=0.196$ & \\
\hline Intercept & $225.30 \pm 66.40$ & 0.003 & $55.09 \pm 91.50$ & 0.566 & $143.41 \pm 119.32$ & 0.269 & $59.93 \pm 0.83$ & 0.434 \\
\hline Chlorophyll b & $22.54 \pm 5.26$ & 0.000 & $22.09 \pm 12.70$ & 0.126 & $13.68 \pm 8.95$ & 0.170 & $11.02 \pm 10.36$ & 0.323 \\
\hline $\mathrm{pH}$ & $-166.17 \pm 45.60$ & 0.002 & $-51.98 \pm 98.05$ & 0.612 & $-146.16 \pm 130.97$ & 0.301 & $-46.33 \pm 60.83$ & 0.471 \\
\hline Diversity & $R^{2}=0.44 ; p=0.0025$ & & $R^{2}=0.41 ; p=0.180$ & & $R^{2}=0.00 ; p=0.72$ & & $R^{2}=0.06 ; p=0.245$ & \\
\hline Intercept & $6.07 \pm 2.46$ & 0.022 & $-0.65 \pm 0.46$ & 0.194 & $0.44 \pm 0.27$ & 0.146 & $-0.43 \pm 0.63$ & 0.507 \\
\hline Transparency & $0.39 \pm 0.13$ & 0.005 & $0.59 \pm 0.25$ & 0.046 & $0.06 \pm 0.15$ & 0.710 & $0.48 \pm 0.38$ & 0.245 \\
\hline Zooplankton & $R^{2}=0.40 ; p=0.011$ & & $R^{2}=0.16 ; p=0.291$ & & $R^{2}=0.54 ; p=0.055$ & & $R^{2}=0.76 ; p=0.026$ & \\
\hline Intercept & $5.88 \pm 13.63$ & 0.671 & $12.39 \pm 3.97$ & 0.021 & $4.94 \pm 1.13$ & 0.005 & $11.60 \pm 3.10$ & 0.010 \\
\hline Transparency & $-3.23 \pm 0.74$ & 0.000 & $-3.10 \pm 1.74$ & 0.125 & $-0.63 \pm 0.70$ & 0.402 & $-5.32 \pm 1.64$ & 0.017 \\
\hline Chlorophyll b & $-3.22 \pm 1.11$ & 0.009 & $-3.82 \pm 2.67$ & 0.203 & $-3.82 \pm 1.12$ & 0.015 & $-0.68 \pm 2.48$ & 0.793 \\
\hline Salinity & $1.45 \pm 0.60$ & 0.024 & $-1.11 \pm 1.47$ & 0.476 & $1.45 \pm 1.27$ & 0.296 & $0.79 \pm 0.77$ & 0.344 \\
\hline Copepods & $R^{2}=0.39 ; p=0.012$ & & $R^{2}=0.20 ; p=0.255$ & & $R^{2}=0.74 ; p=0.010$ & & $R^{2}=0.63 ; p=0.029$ & \\
\hline Intercept & $17.93 \pm 7.62$ & 0.028 & $9.85 \pm 3.49$ & 0.030 & $5.33 \pm 0.97$ & 0.002 & $13.12 \pm 3.30$ & 0.007 \\
\hline Transparency & $-3.27 \pm 0.78$ & 0.000 & $-3.15 \pm 1.73$ & 0.118 & $-0.79 \pm 0.61$ & 0.242 & $-5.53 \pm 1.73$ & 0.019 \\
\hline Chlorophyll b & $-3.97 \pm 1.20$ & 0.003 & $-3.81 \pm 2.42$ & 0.166 & $-4.78 \pm 0.95$ & 0.002 & $-7.50 \pm 6.97$ & 0.323 \\
\hline Chlorophyll a & $3.03 \pm 1.09$ & 0.012 & $3.14 \pm 3.55$ & 0.411 & $2.26 \pm 0.89$ & 0.044 & $6.06 \pm 6.42$ & 0.382 \\
\hline Nauplii & $R^{2}=0.38 ; p=0.015$ & & $R^{2}=0.21 ; p=0.249$ & & $R^{2}=0.66 ; p=0.022$ & & $R^{2}=0.75 ; p=0.031$ & \\
\hline Intercept & $15.03 \pm 7.89$ & 0.071 & $8.61 \pm 3.60$ & 0.054 & $4.05 \pm 1.15$ & 0.013 & $11.55 \pm 3.39$ & 0.014 \\
\hline Transparency & $-3.39 \pm 0.81$ & 0.000 & $-3.39 \pm 1.78$ & 0.106 & $-1.00 \pm 0.72$ & 0.216 & $-5.55 \pm 1.78$ & 0.020 \\
\hline Chlorophyll b & $-3.96 \pm 1.24$ & 0.004 & $-3.77 \pm 2.50$ & 0.181 & $-4.70 \pm 1.12$ & 0.006 & $6.59 \pm 6.60$ & 0.357 \\
\hline Chlorophyll $a$ & $2.87 \pm 1.13$ & 0.019 & $3.10 \pm 3.67$ & 0.430 & $2.12 \pm 1.05$ & 0.091 & $-8.00 \pm 7.17$ & 0.307 \\
\hline Acartia tonsa & $R^{2}=0.52 ; p=0.001$ & & $R^{2}=0.00 ; p=0.577$ & & $R^{2}=0.10 ; p=0.445$ & & $R^{2}=0.00 ; p=0.831$ & \\
\hline Intercept & $14.27 \pm 5.38$ & 0.015 & $47.35 \pm 47.53$ & 0.376 & $-4.06 \pm 20.21$ & 0.851 & $-1.96 \pm 5.87$ & 0.755 \\
\hline Salinity & $1.72 \pm 0.44$ & 0.001 & $-4.42 \pm 3.69$ & 0.296 & $-1.68 \pm 2.08$ & 0.465 & $0.23 \pm 0.42$ & 0.610 \\
\hline Chlorophyll a & $2.23 \pm 0.72$ & 0.005 & $-3.97 \pm 2.92$ & 0.245 & $2.78 \pm 1.54$ & 0.145 & $0.23 \pm 2.39$ & 0.929 \\
\hline Chlorophyll b & $-2.16 \pm 0.77$ & 0.011 & $1.97 \pm 5.37$ & 0.732 & $-1.53 \pm 1.21$ & 0.276 & $0.57 \pm 2.62$ & 0.840 \\
\hline $\mathrm{pH}$ & $-14.00 \pm 5.57$ & 0.020 & $-44.55 \pm 44.90$ & 0.377 & $6.42 \pm 23.21$ & 0.796 & $1.98 \pm 5.96$ & 0.757 \\
\hline Transparency & $-1.22 \pm 0.52$ & 0.028 & $2.46 \pm 2.13$ & 0.312 & $-0.60 \pm 0.81$ & 0.500 & $-0.14 \pm 0.67$ & 0.847 \\
\hline Marine Rotifers & $R^{2}=0.30 ; p=0.033$ & & $R^{2}=0.22 ; p=0.170$ & & $R^{2}=0.56 ; p=0.022$ & & $R^{2}=0.00 ; p=0.528$ & \\
\hline Intercept & $-31.44 \pm 17.10$ & 0.080 & $-90.35 \pm 58.55$ & 0.167 & $81.78 \pm 22.95$ & 0.009 & $-24.28 \pm 26.44$ & 0.389 \\
\hline Salinity & $2.04 \pm 0.79$ & 0.017 & $3.90 \pm 2.35$ & 0.140 & $2.76 \pm 1.56$ & 0.120 & $16.65 \pm 18.37$ & 0.395 \\
\hline Temperature & $25.31 \pm 12.19$ & 0.050 & $61.63 \pm 41.21$ & 0.178 & $-57.75 \pm 16.62$ & 0.010 & $1.22 \pm 1.10$ & 0.303 \\
\hline Feshw. rotifers & $R^{2}=0.50 ; p=0.003$ & & $R^{2}=0.69 ; p=0.018$ & & $R^{2}=0.00 ; p=0.726$ & & $R^{2}=0.76 ; p=0.008$ & \\
\hline Intercept & $50.94 \pm 15.57$ & 0.004 & $53.31 \pm 30.04$ & 0.126 & $22.52 \pm 22.41$ & 0.354 & $10.25 \pm 8.45$ & 0.270 \\
\hline Chlorophyll b & $4.39 \pm 1.23$ & 0.002 & $3.17 \pm 3.29$ & 0.372 & $1.04 \pm 3.43$ & 0.772 & $5.06 \pm 1.44$ & 0.013 \\
\hline $\mathrm{pH}$ & $-30.40 \pm 11.39$ & 0.015 & $-54.96 \pm 31.01$ & 0.127 & $-24.07 \pm 24.62$ & 0.366 & $-11.59 \pm 8.67$ & 0.230 \\
\hline Chlorophyll c & $-1.79 \pm 0.79$ & 0.036 & $-3.18 \pm 1.40$ & 0.064 & $0.11 \pm 3.36$ & 0.974 & $1.21 \pm 3.73$ & 0.757 \\
\hline
\end{tabular}

Equation parameters of the multiple linear regression models using forward stepwise method explaining the variations of the main zooplankton parameters. Significant $p$ values $(p<0.05)$ are in bold characters. 


\section{Multivariate analysis (coinertia)}

The first factorial plane of the coinertia analysis explained $57 \%$ of the variance, of which $34 \%$ were attributed to the first axis and $23 \%$ to the second.

In both 'environment' and 'zooplankton' structures, axis 1 showed a distinction between the rainy season (R1 to R10 but particularly R8) and the two other surveys (N and D) (Figure 6A). $\mathrm{R}$ samples were characterized by high $\mathrm{NO}_{3}, \mathrm{NO}_{2}$ temperature, transparency, depth, and chlorophyll $a$ values (Figure 6B). They were also associated with several taxa: Appendicularia, Oncaea venusta, Corycaeus spp., S. oblonga, and S. bicornis (Figure 6A). $\mathrm{N}$ and $\mathrm{D}$ samples were correlated with environmental $\left(\mathrm{NH}_{4}\right.$, salinity, $\mathrm{pH}$, bacterial biomass) and zooplankton variables (L. quadridentata, L. bulla, T. patina, P. quadricornis, gastropod larvae). The second axis mainly opposed the $\mathrm{N}$ samples (particularly $\mathrm{N} 1$ ) to the D samples (except D2 and D3) (Figure 6D). The $\mathrm{N}$ samples were characterized by high $\mathrm{PO}_{4}$ and chlorophyll $b$ values, by high oxygen gradients (d Oxy), and by harpacticoid copepod (Canuella sp.). The D samples were characterized by high salinity, depth, transparency, and chlorophyll $c$ values and by coastal marine or brackishwater zooplankton taxa: A. tonsa, P. aculeatus, E. acutifrons, $B$. plicatilis, and polychaete larvae.

\section{Discussion}

\section{Environmental and trophic context}

Our study highlighted high time and space variability of abiotic and biotic variables in the Sontecomapan lagoon. This can be linked to the shallowness of the lagoon (up to $7 \mathrm{~m}$ in the main channel and 0.4 to $2.5 \mathrm{~m}$ for the sampled stations in our study) and to the high influence of permanent exchanges with the ocean and of seasonal freshwater inflows. The exchanges with the ocean through the permanently opened pass are conditioned by tidal influence which must be important, as tidal amplitudes were $1.03,0.87$, and $0.83 \mathrm{~m}$ during the dry, rainy, and norte surveys, respectively (tablademareas.com 2013). Despite no data is available on the residence time, we can suppose
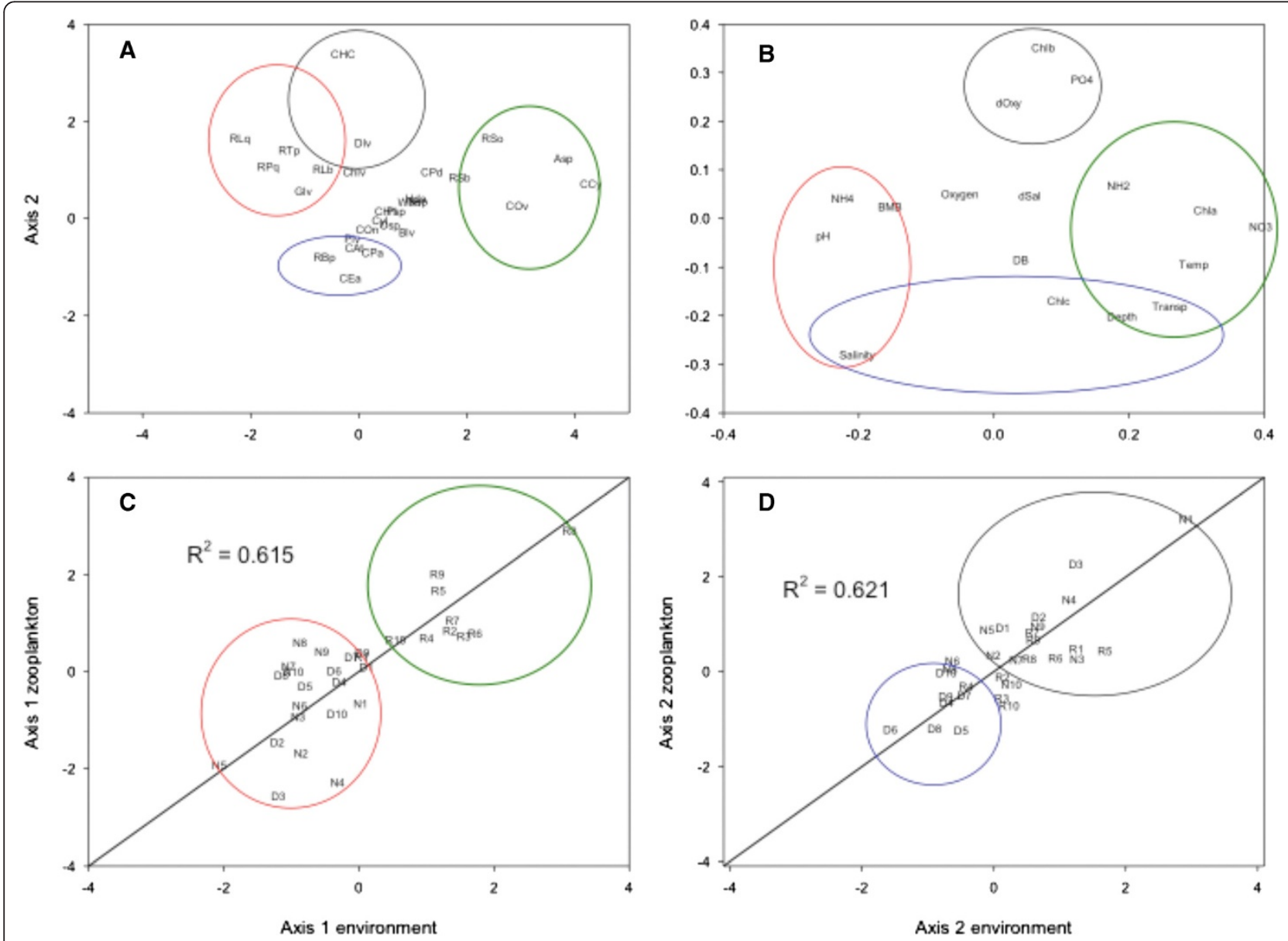

Figure 6 Co-inertia analysis. Ordination on the plan $(1,2)$ of taxa $(\mathbf{A})$ and environmental variables (B) and plots of the sampling points on the first (C) and second (D) axes of the two systems. The line represents the equality between the coordinates on the two systems. Symbols are in Tables 2 and 3. dSal and dOxy are salinity and oxygen differences between surface and bottom. Symbols of sampling points the letters $\mathrm{N}$, R, or D (for norte, rainy, or dry surveys) followed by the station number. 
that the water renewal linked to tidal-driven exchanges was globally important in the major part of the lagoon, as suggested by the low percentages of organic matter and fine particles (silt and clays) in the sediment, except at station 3 situated in a slack water zone (see Figure 1).

The fresh water inflow comes mainly from three small rivers (La Palma, Basura, and Sabalo), and despite no data is available on their flows, we can consider that their influence is seasonally important as we observed significant salinity decrease during the rainy survey. Besides these, freshwater inputs presumably provoked important nitrate increase during the rainy season and local $\mathrm{pH}$ decrease near the mouth of the rivers, down to $<7$ at stations 1 and 7 (Basura and La Palma rivers).

Tidal exchanges with the ocean and seasonal fresh water inputs in this shallow lagoon explain the high variability in abiotic and biotic variables thus causing season-specific differences. During the rainy survey (June), high nutrient concentrations (mainly $\mathrm{NO}_{3}$ ) probably stimulated phytoplankton production explaining the high chlorophyll $a$ concentration. During the dry and norte surveys, high salinity and $\mathrm{pH}$ illustrated the resalinization of the lagoon linked to the scarcity of freshwater inputs. During the dry season survey, high ammonium concentration and high bacterial biomass suggested remineralization processes through the microbial loop and the excretion of planktonic organisms. At this period, high chlorophyll $c$ concentration also suggested a specific phytoplankton community characterized by chrysophytes, cryptophytes, diatoms, and dinoflagellates according to the diagnostic for phytoplankton functional groups in natural estuarine and coastal communities (Paerl et al. 2003). In contrast, norte season was characterized by higher $\mathrm{PO}_{4}$ values (and thus lower N/P ratios), perhaps explaining another phytoplankton community as suggested by higher chlorophyll $b$ values characterized more by euglenophytes and prasinophytes (Paerl et al. 2003). Aké-Castillo and Vázquez (2008) have recorded 179 phytoplankton taxa (mainly diatoms and dinoflagellates) in the Sontecomapan lagoon and the three rivers draining into it. They also found peaks of phytoplank-

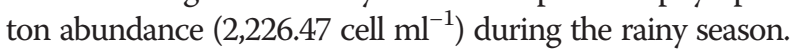

In a complex lagoon system, the variability of the nutrient concentration and composition may also result from the diversity of the input sources. In Sontecomapan, only the litterfall of mangrove forest (Rhizophora mangle) represents significant loads of organic matter available for decomposition $\left(1.1 \mathrm{Kg} \cdot \mathrm{m}^{-2}\right.$ ) (Aké-Castillo et al. 2006) and which may contribute to phytoplankton dynamics (Aké-Castillo and Vázquez 2008). But nutrients are cycled by a variety of biogeochemical processes (Eyre 2000; Eyre and McKee 2002), where bacteria are key in controlling the trophic linkages in aquatic ecosystems (Bianchi 2007).
Nevertheless, in terms of environmental conditions, the three study periods in Sontecomapan can be distinguished either on salinity conditions or on the basis of the nutrient and trophic status leading to different phytoplankton assemblages and thus different trophic condition for zooplankton.

\section{Composition and abundance of zooplankton}

This was the first complete study dealing with all the zooplankton groups in Sontecomapan. The taxonomic composition described in the present work is typical of brackish water zooplankton assemblages (Ferrari et al. 1982; Arfi et al. 1987; Étile et al. 2009). It has also similar characteristics with other Mexican coastal lagoons of the Yucatan Peninsula on the Gulf of Mexico (Chelem lagoon, Escamilla et al. 2001; Bojorquez lagoon, ÁlvarezCadena et al. 1996; Nichupté lagoon, Álvarez-Cadena et al. 2007). All these studies in Caribbean Mexican lagoons reported the dominance of copepods and $A$. tonsa, probably due to wider mesh size of zooplankton nets ( 200 or 330 vs. $64 \mu \mathrm{m}$ in this study) neither the importance of Oithona species or the occurrence of rotifers was dealt.

Between the identified groups of zooplankton, the rotifers were the most diverse (21 species belonging to 8 families), due to the fresh water influence in the lagoon. Contrastingly, this phylum represented only $3.7 \%$ of the freshwater species reported for the neotropical region (Segers 2008) and 5.7\% of total species recorded from Mexico (Benitez Diaz-Mirón, unpubl. data). The rotifer richness in Sontecomapan in the present study is low compared to the 250 species expected in tropical freshwater bodies (Segers 2008). It is also low as compared to the 60 species reported previously for the Sontecomapan lagoon (Castellanos-Páez et al. 2005). Besides, we found only 12 species of this previous investigation, while we reported 9 species for the first time in the lagoon, changing the current rotifer inventory to 69 species. This rotifer taxa richness is higher than the 37 taxa reported by (Sarma et al. 2000), in another brackish lagoon in Mexico (Mecoacan, Tabasco). In this lagoon, these authors reported only one cladoceran species (Moina minuta) which is also lower than the three cladoceran species identified in our study (Ceriodaphnia sp., Chydorus sp., and P. avirostris).

After the rotifers, the copepods were the most diverse group in our study, 15 free living copepods taxa were identified (see Table 3), of which 4 are recorded for the first time in coastal lagoons of the state of Veracruz $(O$. nana, Canuella sp., Phenna sp., and Tisbe sp.), according to the list of 23 species by Álvarez-Silva and GómezAguirre (2000). Around 100 freshwater and 479 marine copepod species have been determined in Mexican waters (Elías-Gutiérrez et al. 2008). The number of brackish species is still very small, as most studies about brackish 
copepods were oriented towards the description of new species or first records (Barranco-Ramírez and Gómez 2001; Gómez 2006; Morales-Serna and Gómez 2008) or to inventories of host-parasite copepods (Morales-Serna et al. 2012).

The most abundant copepods identified in the present work, A. tonsa (Dana), is a calanoid copepod species having a cosmopolitan distribution, being the dominant copepod in many subtropical and temperate coastal marine and estuarine areas (Peck and Holste 2006). As in our study, it has been often found coexisting with $O$. nana (Richard and Jamet 2001; Delpy et al. 2012).

Low zooplankton densities were also reported for other shallow Mexican Caribbean lagoon by Álvarez-Cadena et al. (1996) and Escamilla et al. (2001).

To explain these low zooplankton densities, different hypotheses can be advanced on the light of our results. A first hypothesis is linked to the instable conditions for zooplankton related to high variability of environmental and trophic conditions associated to the shallowness of the lagoon and the combined influence of freshwater and marine inputs (see Discussion above). Accordingly, several studies have shown negative impacts of disturbance or instability of hydrological, abiotic, and trophic conditions on zooplankton (Eckert and Walz 1998; Gascon et al. 2007). A second hypothesis is linked to the negative correlations between transparency and total or more abundant (nauplii, copepods, A. tonsa) zooplankton suggested (i) negative effect to the UV radiation (Leech and Williamson 2001) and (ii) vulnerability of zooplankton to visual predation (Williamson et al. 2011). This should be particularly problematic in very shallow ecosystems, such as Sontecomapan, where transparency reach up to the bottom in most situations and, scarcity of vegetation (submerged or floating macrophytes), imply lack of refuges for zooplankton against these threats. In contrast, some of the highest zooplankton densities $\left(>3,000,000\right.$ ind. $\left.\mathrm{m}^{-3}\right)$ reported for tropical coastal lagoons were observed in Imbossica Lagoon (Brazil), which is a turbid ecosystem with a highly macrophyte colonized littoral zone (Kozlowsky-Suzuki and Bozelli 2004). Besides, the scarcity of cladocerans in the Sontecomapan lagoon (only three species and $<2 \%$ abundance) agree with the hypothesis of negative impact of light conditions. In laboratory experiments, cladocerans (Daphnia spp.) were shown to be less UV-tolerant than copepods or rotifers regardless of the UVR transparency of their source lake (Leech et al. 2005). Additionally, cladocerans have been shown to be very sensitive to visual predation (Vinyard 1980; Ramcharan et al. 2009).

\section{Factors controlling zooplankton community}

In this study, the relationship between biotic or abiotic conditions and zooplankton clearly appeared in the multiple regression analysis (see Table 4) and in the coinertia analysis, which discriminated the three seasons on the basis of both environmental and zooplankton data sets (see Figure 6). The biotic processes in aquatic ecosystems could be acting separately or in tandem with abiotic forces in structuring planktonic communities at scales relevant to organisms, populations, and ecosystems (Gal et al. 2013).

As suggested by the results of the multivariate analysis, transparency (associated with salinity) probably drove the differences observed between zooplankton communities during the dry and norte surveys. Taxa of marine origin were associated to the more transparent waters during the dry season, while meiobenthic forms (the harpacticoid copepod Canuella sp) characterized the zooplankton during the more turbid norte survey. At this period, the presence of meiobenthic organisms in the plankton can be explained by the occurrence of strong winds driving wind resuspension of sediment and the mixing of meiobenthic forms with the plankton as also observed in other shallow coastal ecosystems (Lawrence et al. 2004).

The role of $\mathrm{pH}$ in structuring the seasonal variations of zooplankton clearly appeared in the coinertia analysis through its tight relationships with the community characterizing the norte and dry surveys. The $\mathrm{pH}$ was also negatively correlated to the taxonomic richness or to the abundance of $A$. tonsa and freshwater rotifers. The sensitivity of freshwater rotifers to high $\mathrm{pH}$ values has been evidenced in several studies (Bērzinš and Pejler 1987). Only few studies examined the relationships between $\mathrm{pH}$ and copepod species. Similar to our results, Chew and Chong (2011) found negative relationship between $\mathrm{pH}$ and several estuarine Acartia species.

Temperature showed significant positive relationships with abundance of marine rotifers. The positive influence of temperature on zooplankton in temperate conditions is well documented [e.g., meta-analyze in Sweden waterbodies (Bērzinš and Pejler 1989)], but in tropical areas, due to the lower range variation, the role of temperature is less evident despite increases in zooplankton abundance during the warmest periods have been also documented (Azevedo and Bonecker 2003; Kâ et al. 2012).

The role of salinity also appeared as driving the differences between the three seasonal surveys as well as through positive correlations with $A$. tonsa and marine rotifers. The highest salinity occurred during the dry survey when the zooplankton community was characterized by organisms such as the copepods Acartia tonsa, $P$. aculeatus, E. acutifrons, the rotifer B. plicatilis, and polychaete larvae which are very common in coastal oceanic areas or in coastal lagoons (David et al. 2007). Acartia and Paracalanus species as well as E. acutifrons generally 
constitute the bulk of the copepod community in most coastal lagoons (Carli and Crisafi 1983). Populations of A. tonsa persist in both coastal marine waters as well as within estuaries having low salinity [e.g., 4 psu, Gulf of Finland, Baltic Sea (Katajisto et al. 1998)]. They can be also abundant in coastal lagoons within a wide salinity range [e.g., 5 to 36 psu; Berre Lagoon, south of France, Mediterranean (Delpy et al. 2012)], despite that it was demonstrated that this species shows high mortalities responding to high changes of salinity [ $>10$ to $15 \mathrm{psu}$ (Cervetto et al. 1999)]. The role of salinity in shaping rotifer communities has also been demonstrated (Malekzadeh Viayeh and Špoljar 2012).

The role of phytoplankton abundance and composition in structuring the zooplankton community appeared in the coinertia analysis through the association of the different forms of chlorophyll $(a, b$, and $c)$ with the zooplankton communities of the three seasonal surveys. It was also evidenced in the regression analysis through (i) the positive relationships between chlorophyll $a$ and copepods, nauplii, or $A$. tonsa, (ii) the relationships of chlorophyll $b$ with total zooplankton, copepods, nauplii, or $A$. tonsa $(<0)$ and with taxonomic richness, diversity or freshwater rotifers $(>)$, and (iii) the negative relationship of chlorophyll $c$ with rotifers.

Negative or positive correlations between zooplankton parameters and the different forms of chlorophyll $(a, b$, or $c$ ) suggest the importance of phytoplankton composition and abundance for the distribution and abundance of zooplankton. Variations in the proportion and abundance of edible and inedible (or toxic) phytoplankton food particles are known to drive variations in zooplankton composition and abundance (Pont 1995). Here, the clear seasonal variations of the chlorophyll forms (Figure 4) reveal variations in phytoplankton assemblages and thus variations in food composition and abundance for herbivorous zooplankton.

High chlorophyll $a$, the most common pigment contained in all photosynthetic algae and cyanobacteria (Paerl et al. 2003), reflects abundance of the most edible phytoplankton forms for zooplankton, such as chlorophytes and diatoms. Its positive relationship with $A$. tonsa and copepod nauplii suggests a clear food dependence for copepods in Sontecomapan. Food dependence of copepods (and Acartia species) has been observed in other eutrophic coastal lagoons (Cervetto et al. 1993; Pagano et al. 2003). The association of high chlorophyll a with appendicularians during the rainy survey (coinertia analysis, Figure 6) also reflects the high feeding efficiency of these organisms on phytoplankton (up to almost $1 \mathrm{~L}$ ind $^{-1}$ day $^{-1}$ ) (Fernandez et al. 2004; Lombard et al. 2009). Besides, the association of appendicularians with $O$. venusta and Corycaeus spp. can be explained by the feeding behavior of these two cyclopid copepods, which can use small particles aggregated on settling appendicularian houses (Turner 2004).

Negative relationships between chlorophyll $b$ or chlorophyll $c$ and zooplankton (see Table 4) may reflect importance of inedible or toxic forms in the available phytoplankon. Chlorophyll $c$ (and particularly the forms $c_{1}$ and $c_{2}$ considered in this study) is characteristic of dinoflagellates and diatoms, of which several species may be toxic to zooplankton (Granéli and Turner 2006). However, the absence of concomitant data on phytoplankton composition does not allow us to draw further conclusion.

The partial regression analysis did not show any direct relationship between zooplankton parameters and the bacterial biomass. Bacteria can be punctually an alternative direct or indirect carbon source for the zooplankton, mainly for the rotifers (Agasild and Nõges 2005), as observed in other windy and shallow ecosystems. In a shallow subtropical bay in Florida, wind events were shown to inject dissolved and particulate benthic materials into the water column, where they directly stimulated the bacterioplankton, phytoplankton, and zooplankton community (Lawrence et al. 2004). It has been observed that B. plicatilis can consume up to $36 \%$ of the bacterial production while only $<1 \%$ can be harvested by the metazooplankton when copepods are dominant (Bouvy et al. 1994). Generally, the bacterioplankton is not associated positively to the copepods due to their low feeding efficiently on small particles. Nevertheless, small cyclopoid nauplii (such as O. nana) have been shown to ingest (and prefer) very small particles [2 to $5 \mu \mathrm{m}$, (Böttjer et al. 2010)] and thus can represent an important trophic link between the classical and microbial food webs.

\section{Conclusions}

Our study highlighted spatiotemporal variability in zooplankton abundance and composition in relation to high variability of abiotic and trophic context in the Sontecomapan Lagoon. Spatial patterns could not be detected for most variables, but clear differences were recorded among the three seasons. These differences were mainly explained by water transparency, salinity, temperature, $\mathrm{pH}$, and food availability (Chl $a, b$, and $c$ as proxy for phytoplankton abundance and composition), which can be considered as the main structuring forces for the zooplankton in the lagoon.

Combined effects of high water exchange, low depth, and high transparency may explain the relatively lower zooplankton density in the lagoon (compared to other eutrophic lagoons) by favoring instability and vulnerability to UV effects and/or to visual predation.

\section{Competing interests}

The authors declare that they have no competing interests. 


\section{Authors' contributions}

MIBDM, MECP and GGM conceived and designed the study. MIBDM and GGM participated in the field sampling and carried out the laboratory analysis. MECP helped in drafting the manuscript. GGM supported the taxonomic determinations of rotifers. MJFG provided advice for bacterial quantification. MP participated in the taxonomic identification of copepods, analysis of data and drafting the manuscript. All authors read and approved the final manuscript.

\section{Acknowledgements}

The authors are thankful for the financial support contributed by the program of cooperation France-Mexico ECOS-ANUIES 2010-2014. MIBDM is thankful for the scholarship granted by the CONACyT (227103/46776) for the degree of Doctor in Biological Sciences and Health that she obtained. We are grateful to the two anonymous referees for their time and effort which helped us to substantially improve the manuscript.

\section{Author details}

${ }^{1}$ Universidad Autónoma Metropolitana, Unidad Xochimilco, Doctorado en Ciencias Biológicas y de la Salud, Calzada del Hueso 1100, Col Villa Quietud, Delegación Coyoacán CP 04960DF, México. ²Universidad Autónoma Metropolitana, Unidad Xochimilco, Departamento el Hombre y su Ambiente, Laboratorio de Rotiferología y Biología Molecular de Plancton, Calzada del Hueso 1100, Col Villa Quietud, Delegación Coyoacán CP 04960DF, México. ${ }^{3}$ Universidad Autónoma Metropolitana, Unidad Xochimilco, Departamento el Hombre y su Ambiente, Laboratorio de Ecología Microbiana, Calzada del Hueso 1100, Col Villa Quietud, Delegación Coyoacán CP 04960DF, México. ${ }^{4}$ Aix-Marseille University, CNRS, University of Toulon, IRD, MIO UM 110, Marseille, France.

Received: 24 November 2013 Accepted: 26 August 2014 Published online: 05 September 2014

\section{References}

Agasild H, Nõges T (2005) Cladoceran and rotifer grazing on bacteria and phytoplankton in two shallow eutrophic lakes: in situ measurement with fluorescent microspheres. J Plankton Res 27(11):1155-1174

Aké-Castillo JA, Vázquez G (2008) Phytoplankton variation and its relation to nutrients and allochthonous organic matter in a coastal lagoon on the Gulf of Mexico. Estuar Coast Shelf Sci 78(4):705-714

Aké-Castillo JA, Vázquez G (2011) Peridinium quinquecorne var. trispiniferum var. nov. (Dinophyceae) from a brackish environment. Acta Botánica Mexicana 94:125-140

Aké-Castillo J, Vázquez G, López-Portillo J (2006) Litterfall and decomposition of Rhizophora mangle L. in a coastal lagoon in the Southern Gulf of Mexico. Hydrobiologia 559(1):101-111, doi:10.1007/s10750-005-0959-x

Álvarez-Cadena JN, Islas-Landeros ME, Suárez-Morales E (1996) A preliminary zooplankton survey in a Mexican Caribbean eutrophic coastal lagoon. Bull Mar Sci 58(3):694-708

Álvarez-Cadena JN, Ordóñez-López U, Valdés-Lozano D, Almaral-Mendívil AR, Uicab-Sabido A (2007) Estudio anual del zooplancton: composición, abundancia, biomasa e hidrología del norte de Quintana Roo, mar Caribe de México. Rev Mex Biodivers 78:421-430

Álvarez-Cadena JN, Ordoñez-López U, Almaral-Mendivil AR, Uicab-Sabido A (2009) Composition and abundance of zooplankton groups from a coral reef lagoon in Puerto Morelos, Quintana Roo, Mexico, during an annual cycle. Rev Biol Trop 57(3):647-658

Álvarez-Silva C, Gómez-Aguirre S (2000) Updated list of copepods (Crustacea) of the coastal lagoons from Veracruz. Hidrobiologica 10(2):161-168

Arfi R, Pagano M, Saint Jean L (1987) Zooplankton communities in a tropical lagoon (Ebrie Lagoon, Cote d'Ivoire): time-space variations communautes zooplanctoniques dans une lagune tropicale (la lagune Ebrie, Cote d'Ivoire). Rev Hydrobiol Trop 20(1):21-35

Azevedo F, Bonecker CC (2003) Community size structure of zooplanktonic assemblages in three lakes on the upper River Paraná floodplain, PR-MS, Brazil. Hydrobiologia 505:147-158

Barranco-Ramírez E, Gómez S (2001) Supplementary description and illustrated record of Monstrilla gibbosa Suárez-Morales \& Palomares-García, 1995 (Copepoda, Monstrilloida) from Sinaloa, Mexico. Crustaceana-International Journal of Crustacean Research 74(11):1279-1290
Bartoli M, Castaldelli G, Nizzoli D, Gatti LG, Viaroli P (2001) Benthic fluxes of oxygen, ammonium and nitrate and coupled-uncoupled denitrification rates within communities of three different primary producer growth forms. In: Faranda FM, Guglielmo L, Spezie GC (eds) Mediterranean ecosystems. Springer, Milan, pp 225-233, doi:10.1007/978-88-470-2105-1-29

Bērzinš B, Pejler B (1987) Rotifer occurrence in relation to $\mathrm{pH}$. Hydrobiologia 147(1):107-116, doi:10.1007/bf00025733

Bērzinš B, Pejler B (1989) Rotifer occurrence in relation to temperature. Hydrobiologia 175(3):223-231

Bianchi TS (2007) Biogeochemistry of estuaries. Oxford University Press, New York

Bjørnsen PK (1986) Automatic determination of bacterioplankton biomass by image analysis. Appl Environ Microbiol 51(6):1199-1204

Böttjer D, Morales CE, Bathmann U (2010) Trophic role of small cyclopoid copepod nauplii in the microbial food web: a case study in the coastal upwelling system off central Chile. Mar Biol 157(4):689-705

Bouvy M, Arfi R, Guiral D, Pagano M, Saint-Jean L (1994) Role of bacteria as food for zooplankton in a eutrophic tropical pond (Ivory Coast). Netherland Journal of Aquatic Ecology 28(2):167-174

Bouyoucos GJ (1962) Hydrometer method improved for making particle size analysis of soil. Agron J 54:464-465

Carli A, Crisafi P (1983) Copepodi lagunari. Guide per il riconoscimento delle specie animali delle acque lagunari e costiere iltliane. Consiglio Nazionale delle Ricerche Italy

Castellanos-Páez ME, Garza-Mourino G, Ferrara-Guerrero MJ (2005) Rotifers (Rotifera) of Sontecomapan, Veracruz, a coastal lagoon of Mexico. Scientiae Naturae 8(1):15-27

Cervetto G, Gaudy R, Pagano M, Saint Jean L, Verriopoulos G, Arfi R, Leveau M (1993) Diel variations in Acartia tonsa feeding, respiration and egg production in a Mediterranean coastal lagoon. J Plankton Res 15(11):1207-1228

Cervetto G, Gaudy R, Pagano M (1999) Influence of salinity on the distribution of Acartia tonsa (Copepoda, Calanoida). J Exp Mar Biol Ecol 239(1):33-45

Chew LL, Chong VC (2011) Copepod community structure and abundance in a tropical mangrove estuary, with comparisons to coastal waters. Hydrobiologia 666(1):127-143

Contreras F (1993) Ecosistemas costeros mexicanos, 1st edn. Universidad Autónoma Metropolitana Unidad Iztapalapa, Mexico

David V, Sautour B, Galois R, Chardy P (2006) The paradox high zooplankton biomass-low vegetal particulate organic matter in high turbidity zones: what way for energy transfer? J Exp Mar Biol Ecol 333(2):202-218, doi:10.1016/j.jembe.2005.12.045

David V, Sautour B, Chardy P (2007) Successful colonization of the calanoid copepod Acartia tonsa in the oligo-mesohaline area of the Gironde estuary (SW France)-natural or anthropogenic forcing? Estuar Coast Shelf Sci 71(3):429-442

De Senerpont LN, Elser JJ, Gsell AS, Huszar VLM, Ibelings BW, Jeppesen E, Kosten S, Mooij WM, Roland F, Sommer U, Van Donk E, Winder M, Lürling M (2013) Plankton dynamics under different climatic conditions in space and time. Freshw Biol 58(3):463-482, doi:10.1111/fwb.12053

De Silva-Davila R, Palomares-Garcia R, Zavala-Norzagaray A, Escobedo-Urias DC (2006) Annual cycle of the zooplankton dominant groups in Navachiste. Sinaloa. Instituto de Ciencias del Mar y Limnologia, UNAM, Mazatlan (Mexico)

Delpy F, Pagano M, Blanchot J, Carlotti F, Thibault-Botha D (2012) Man-induced hydrological changes, metazooplankton communities and invasive species in the Berre Lagoon (Mediterranean Sea, France). Mar Pollut Bull 64(9):1921-1932

Doledec S, Chessel D (1994) Co-inertia analysis: an alternative method for studying species - environment relationships. Freshw Biol 31(3):277-294

Eckert B, Walz N (1998) Zooplankton succession and thermal stratification in the polymictic shallow Muggelsee (Berlin, Germany): a case for the intermediate disturbance hypothesis? Hydrobiologia 387:199-206

Elías-Gutiérrez M, Suárez-Morales E, Gutiérrez-Aguirre M, Silva-Briano M, Granados J, Garfias T (2008) Cladocera y Copepoda de las aguas continentales de México. ECOSUR/UNAM-Iztacala/CONABIO/CONACYT, México

Escamilla JB, Suárez-Morales E, Gasca R (2001) Zooplankton distribution during opposite tidal directions in the Chelem lagoon complex, Yucatan, Mexico. Rev Biol Trop 49(1):47-51

Étile RN, Kouassi AM, Aka MN, Pagano M, N’Douba V, Kouassi NJ (2009) Spatio-temporal variations of the zooplankton abundance and composition in a West African tropical coastal lagoon (Grand-Lahou, Côte d'Ivoire). Hydrobiologia 624(1):171-189, doi:10.1007/s10750-008-9691-7 
Eyre BD (2000) Regional evaluation of nutrient transformation and phytoplankton growth in nine river-dominated sub-tropical east Australian estuaries. Mar Ecol Prog Ser 205(61):83

Eyre BD, McKee LJ (2002) Carbon, nitrogen, and phosphorus budgets for a shallow subtropical coastal embayment (Moreton Bay, Australia). Limnol Oceanogr 47(4):1043-1055

Fernandez D, Lopez Urrutia A, Fernandez A, Acuna JL, Harris R (2004) Retention efficiency of 0.2 to $6 \mu \mathrm{m}$ particles by the appendicularians Oikopleura dioica and Fritillaria borealis. Mar Ecol Prog Ser 266:89-101

Ferrari I, Ceccherelli VU, Mazzocchi MG (1982) Structure du zooplankton dans deux lagunes du Delta du Pô. Oceanologica Acta V 4:293-302

Gal G, Skerjanec M, Atanasova N (2013) Fluctuations in water level and the dynamics of zooplankton: a data-driven modelling approach. Freshw Biol 58(4):800-816, doi:10.1111/fwb.12087

Gascon S, Brucet S, Sala J, Boix D, Quintana XD (2007) Comparison of the effects of hydrological disturbance events on benthos and plankton salt marsh communities. Estuar Coast Shelf Sci 74(3):419-428

Gómez S (2006) Description of Kelleria reducta sp. nov. (Copepoda, Cyclopoida, Kelleriidae) from a brackish system in northwestern Mexico. Crustaceana 79(7):879-892, http://dx.doi.org/10.1163/156854006778008203

Granéli E, Turner JT (2006) Ecology of harmful algae, vol 189. Ecological studies, Springer-Verlag, Berlin-Heidelberg

Jeffrey SW, Humphrey GF (1975) New spectrophotometric equations for determining chlorophylls $a, b$, and $c$, in higher plants, algae and natural phytoplankton. Biochem Physiol Pflanz 167:191-194

Kâ S, Mendoza-Vera JM, Bouvy M, Champalbert G, N'Gom-Kâ R, Pagano M (2012) Can tropical freshwater zooplankton graze efficiently on cyanobacteria? Hydrobiologia 679(1):119-138, doi:10.1007/s10750-011-0860-8

Katajisto T, Viitasalo M, Koski M (1998) Seasonal occurrence and hatching of calanoid eggs in sediments of the northern Baltic Sea. Mar Ecol Prog Ser 163:133-143

Kemp MW, Boynton WR (2012) Synthesis in estuarine and coastal ecological research: what is it, why is it important, and how do we teach it? Estuar Coasts 35:1-22

Kibirige I, Perissinotto R (2003) The zooplankton community of the Mpenjati Estuary, a South African temporarily open/closed system. Estuar Coast Shelf Sci 58(4):727-741, http://dx.doi.org/10.1016/S02727714(03)00180-X

Kirby RR, Beaugrand G, Lindley JA (2008) Climate-induced effects on the meroplankton and the benthic-pelagic ecology of the North Sea. Limnol Oceanogr 53(5):1805

Koste W (1978) Rotatoria Die Rodertiere Mitteleuropas begründet von Max Voigt. - Mongononta B. Borntraeger, Stuttgart

Kozlowsky-Suzuki B, Bozelli RL (2004) Resilience of a zooplankton community subjected to marine intrusion in a tropical coastal lagoon. Hydrobiologia 522(1-3):165-177

Lam-Hoai T, Guiral D, Rougier C (2006) Seasonal change of community structure and size spectra of zooplankton in the Kaw River estuary (French Guiana). Estuar Coast Shelf Sci 68(1-2):47-61, http://dx.doi.org/10.1016/j. ecss.2006.01.009

Lassalle G, Lobry J, Le Loc'h F, Mackinson S, Sanchez F, Tomczak MT, Niquil N (2013) Ecosystem status and functioning: searching for rules of thumb using an intersite comparison of food-web models of Northeast Atlantic continental shelves. ICES J Mar Sci 70(1):135-149

Lawrence D, Dagg MJ, Liu HB, Cummings SR, Ortner PB, Kelble C (2004) Wind events and benthic-pelagic coupling in a shallow subtropical bay in Florida. Mar Ecol Prog Ser 266:1-13

Leech DM, Williamson CE (2001) In situ exposure to ultraviolet radiation alters the depth distribution of Daphnia. Limnol Oceanogr 46(2):416-420

Leech DM, Williamson CE, Moeller RE, Hargreaves BR (2005) Effects of ultraviolet radiation on the seasonal vertical distribution of zooplankton: a database analysis. Archiv Fur Hydrobiologie 162(4):445-464

Lombard F, Renaud F, Sainsbury C, Sciandra A, Gorsky G (2009) Appendicularian ecophysiology I. Food concentration dependent clearance rate, assimilation efficiency, growth and reproduction of Oikopleura dioica. J Mar Syst 78 (4):606-616

Malekzadeh Viayeh R, Špoljar M (2012) Structure of rotifer assemblages in shallow waterbodies of semi-arid northwest Iran differing in salinity and vegetation cover. Hydrobiologia 686(1):73-89, doi:10.1007/s10750-011-0992-x

Marcus N (2004) An overview of the impacts of eutrophication and chemical pollutants on copepods of the coastal zone. Zool Stud 43(2):211-217
Marinov D, Zaldívar JM, Norro A, Giordani G, Viaroli P (2008) Integrated modelling in coastal lagoons: Sacca di Goro case study. Hydrobiologia 611(1):147-165, doi:10.1007/s10750-008-9451-8

Morales-Serna FN, Gómez S (2008) First record and redescription of Tisbella pulchella (Copepoda: Harpacticoida) from the eastern tropical Pacific. Rev Mex Biodivers 79:103-116

Morales-Serna FN, Gomez S, De Leon G-P (2012) Parasitic copepods reported from Mexico. Zootaxa 3234:43-68

Nandini S, Merino-Ibarra M, Sarma SSS (2008) Seasonal changes in the zooplankton abundances of the reservoir Valle de Bravo (State of Mexico, Mexico). Lake Reserv Manag 24(4):321-330, doi:10.1080/07438140809354842

Naumenko EN (2009) Zooplankton in different types of estuaries (using Curonian and Vistula estuaries as an example). Inland Water Biol 2(1):72-81, doi:10.1134/s1995082909010118

Paerl HW, Valdes LM, Pinckney JL, Piehler MF, Dyble J, Moisander PH (2003) Phytoplankton photopigments as indicators of estuarine and coastal eutrophication. Bioscience 53(10):953-964

Pagano M, Kouassi E, Saint Jean L, Arfi R, Bouvy M (2003) Feeding of Acartia clausi and Pseudodiaptomus hessei (Copepoda : Calanoida) on natural particles in a tropical lagoon (Ebrie, Cote d'Ivoire). Estuar Coast Shelf Sci 56(3-4):433-445

Pantaleón-López B, Aceves A, Castellanos IA (2005) Distribution and abundance of zooplankton of the lagoon system Chacahua-La Pastoria, Oaxaca, Mexico. Rev Mex Biodivers 76(1):63-70

Peck MA, Holste L (2006) Effects of salinity, photoperiod and adult stocking density on egg production and egg hatching success in Acartia tonsa (Calanoida: Copepoda): optimizing intensive cultures. Aquaculture 255(1):341-350

Pinel-Alloul B, Ghadouani A (2007) Spatial heterogeneity of planktonic microorganisms in aquatic systems. In: Franklin RB, Mils Al (eds) The spatial distribution of microbes in the environment. Springer Netherlands, pp 203-310

Pinto-Coelho R, Pinel-Alloul B, Méthot G, Havens KE (2005) Crustacean zooplankton in lakes and reservoirs of temperate and tropical regions: variation with trophic status. Can J Fish Aquat Sci 62(2):348-361

Pont D (1995) Le zooplancton herbivore dans les chaînes alimentaires pélagiques. In: Pourriot R, Meybeck M (eds) Limnologie Générale, vol 25. Masson, Collection d'Ecologie, Paris, pp 515-540

Porter KG, Feig YS (1980) The use of DAPI for identifying and counting aquatic microflora. Limnol Oceanogr 25(5):943-948, doi:10.2307/2836068

Ramcharan C, Pangle KL, Peacor SD (2009) Light-dependent predation by the invertebrate planktivore Bythotrephes longimanus. Can J Fish Aquat Sci 66(10):1748-1757

Razouls C, de Bovée F, Kouwenberg J, Desreumaux N (2005-2013) Diversité et répartition géographique chez les Copépodes planctoniques marins., http://copepodes.obs-banyuls.fr

Richard S, Jamet J-L (2001) An unusual distribution of Oithona nana Giesbrecht (1892) (Crustacea: Cyclopoida) in a bay: the case of Toulon Bay (France, Mediterranean Sea). J Coast Res 17(4):957-963

Rico-Martinez R, Silva-Briano M (1993) Contribution to the knowledge of the Rotifera of Mexico. Hydrobiologia 255(256):467-474

Rose M (1933) Faune de France 26. Copépode pélagiques Paris

Santangelo JM, De M Rocha A, Bozelli RL, Carneiro LS, De A Esteves F (2007) Zooplankton responses to sandbar opening in a tropical eutrophic coastal lagoon. Estuar Coast Shelf Sci 71(3-4):657-668, http://dx.doi.org/10.1016/j. ecss.2006.09.021

Sarma SSS, Nandini S, Ramirez Garcia P, Cortes Munoz JE (2000) New records of brackish water Rotifera and Cladocera from Mexico. Hidrobiologica 10 (2):121-124

Segers H (1995) The Lecanidae (Monogononta). Guides to identification of microinvertebrates of continental waters of the World. SPB Academic Publishers, Amsterdam

Segers H (2008) Global diversity of rotifers (Rotifera) in freshwater. Hydrobiologia 595(1):49-59, http://dx.doi.org/10.1007/s10750-007-9003-7

Strickland JH, Parsons TR (1972) A practical handbook of seawater analysis. Fisheries Research Bulletin 167:21-26

Suárez-Morales E (2004) A new species of Eucyclops Claus (Copepoda: Cyclopoida) from Southeast Mexico with a key for the identification of the species recorded in Mexico. Zootaxa 617:1-18

Suárez-Morales E, Elías-Gutiérrez M (2000) Two new Mastigodiaptomus (Copepoda, Diaptomidae) from southeastern Mexico, with a key for the 
identification of the known species of the genus. J Nat Hist 34(5):693-708, doi:10.1080/002229300299363

Suárez-Morales E, Reid JW (1998) An updated list of the free-living freshwater copepods (Crustacea) of Mexico. Southwest Nat 43(2):256-265

Suárez-Morales E, Gutierrez-Aguirre MA, Mendoza F (2011) The Afro-Asian cyclopoid Mesocyclops aspericornis (Crustacea: Copepoda) in eastern Mexico with comments on the distribution of exotic copepods. Rev Mex Biodivers 82(1):109-115

tablademareas.com (2013) http://www.tablademareas.com/

Thioulouse J, Chessel D, Dole'dec S, Olivier J-M (1997) ADE-4: a multivariate analysis and graphical display software. Stat Comput 7(1):75-83, doi:10.1023/ a:1018513530268

Tregouboff G, Rose M (1957) Manuel de planctonologie méditerranéenne, vol 1. Centre National de la Recherche Scientifique, Paris

Turner JT (2004) The importance of small planktonic copepods and their roles in pelagic marine food webs. Zool Stud 43(2):255-266

Vernick E, Hayward T (1984) Determining chlorophyll on the 1984 CALCOF surveys. California Cooperative Oceanic Fisheries Investigations Report 25:74-79

Vinyard GL (1980) Differential prey vulnerability and predator selectivity: effects of evasive prey on bluegill (Lepomis macrochirus) and pumpkinseed (L. gibhosus) predation. Can J Fish Aquat Sci 37:2294-2299

Walkey A, Black IA (1934) An examination of the Degtjareff method for determining organic carbon in soils: effect of variations in digestion conditions and of inorganic soil constituents. Soil Sci 63:251-263

Wallace RL, Walsh EJ, Arroyo ML, Starkweather PL (2005) Life on the edge: rotifers from springs and ephemeral waters in the Chihuahuan Desert, Big Bend National Park (Texas, USA). Hydrobiologia 546(1):147-157, doi:10.1007/s10750005-4112-7

Wallace RL, Walsh EJ, Schröder T, Rico-Martínez R, Rios-Arana JV (2008) Species composition and distribution of rotifers in Chihuahuan Desert waters of Mexico: is everything everywhere? Verh Internat Verein Limnol 30:73-76

Williamson CE, Fischer JM, Bollens SM, Overholt EP, Breckenridge JK (2011) Toward a more comprehensive theory of zooplankton diel vertical migration: integrating ultraviolet radiation and water transparency into the biotic paradigm. Limnol Oceanogr 56(5):1603-1623

doi:10.1186/s40555-014-0059-6

Cite this article as: Benítez-Díaz Mirón et al:: Spatiotemporal variations of zooplankton community in a shallow tropical brackish lagoon

(Sontecomapan, Veracruz, Mexico). Zoological Studies 2014 53:59.

\section{Submit your manuscript to a SpringerOpen ${ }^{\circ}$ journal and benefit from:}

- Convenient online submission

- Rigorous peer review

- Immediate publication on acceptance

- Open access: articles freely available online

- High visibility within the field

- Retaining the copyright to your article

Submit your next manuscript at $\gg$ springeropen.com 